\title{
Parathyroid Carcinoma: Diagnosis and Clinical Implications
}

\author{
Kai DUAN ${ }^{1,2}$, Özgür METE ${ }^{1,2,3}$ \\ 'Department of Pathology, University Health Network, TORONTO, ONTARIO, CANADA, \\ ${ }^{2}$ Department of Laboratory Medicine and Pathobiology, University of Toronto, ONTARIO, CANADA \\ ${ }^{3}$ Endocrine Oncology Site Group, Princess Margaret Cancer Centre, TORONTO, ONTARIO, CANADA
}

\begin{abstract}
Parathyroid carcinoma is a rare type of endocrine cancer, with significant morbidity and mortality associated with parathyroid hormone (PTH)-mediated hypercalcemia. Concerning clinical features for parathyroid cancer include severe hypercalcemia (albumin-corrected calcium $>3 \mathrm{mmol} / \mathrm{L})$, a palpable neck mass $(>3 \mathrm{~cm}), 3 \mathrm{rd} / 2 \mathrm{nd}$ generation PTH assay ratio $(>1)$, and intraoperative suspicion of local invasion or regional metastasis. A definite diagnosis of malignancy is rendered when a parathyroid tumor presents one of the following clinicopathological features: (1) vascular invasion, (2) perineural invasion, (3) gross invasion into adjacent anatomical structures, and/or (4) metastasis. In difficult cases, the use of ancillary biomarkers is critical to establish an accurate diagnosis. Recent advances in molecular pathology have uncovered the important role of CDC73/HRPT2, a tumor suppressor gene deregulated in parathyroid carcinomas. Loss of nuclear and/or nucleolar expression of parafibromin (the gene product of $C D C 73 / H R P T 2$ ) is now regarded as a diagnostic, prognostic and predictive biomarker for parathyroid carcinoma. Furthermore, over 15-20\% of seemingly sporadic parathyroid carcinomas have underlying germline CDC73/HRPT2 mutations. As a result, many centers have integrated the use of ancillary biomarkers, notably parafibromin staining, in their routine practise. Radical surgery with en bloc resection has emerged as a primary treatment modality in parathyroid cancer, achieving cure in some patients. However, in those with inoperable disease, there remains a dire need for new therapies, as current treatments are largely ineffective. This review provides an update on the current knowledge of parathyroid carcinoma and highlights its exciting changes in endocrine practice.
\end{abstract}

Key Words: Parathyroid neoplasms, Hyperparathyroidism, Atypical adenoma, HRPT2 protein, Parafibromin protein

\section{INTRODUCTION}

Parathyroid carcinoma is a highly aggressive endocrine tumor, with an annual incidence of less than 1 per million (1-8). Over $90 \%$ of patients present with excess parathyroid hormone $(\mathrm{PTH})$, representing $<1-5 \%$ of all patients with primary hyperparathyroidism (1,8-11). Despite recent developments in biochemical, radiological and molecular techniques, parathyroid carcinoma remains an elusive disease to recognize clinically and even pathologically in some cases $(1,8,11-14)$. Accurate diagnosis is critical because parathyroid malignancies require more aggressive surgery to decrease the risk of disease recurrence $(7,8,15-19)$. Furthermore, clinical acumen is paramount to ensure their early detection because untreated hyperparathyroidism can lead to severe hypercalcemia and end-organ damage, including renal failure, bone disease, cardiac arrhythmia and neurocognitive dysfunction $(1,8,20)$. When the diagnosis is delayed, patients can present with inoperable or metastatic parathyroid carcinoma, which is often refractory to medical therapy and carries a fatal outcome $(1,4,8)$.

(Turk Patoloji Derg 2015, 31(Suppl):80-97)

Received : 10.06.2015 Accepted : 12.06.2015
In recent years, an oncologic surgical approach, comprising of at least "en bloc" resection of the parathyroid lesion with ipsilateral hemithyroidectomy, has emerged as the standard of care in parathyroid carcinoma $(3,7,8,15,17,20$ 23). Given the lack of specific preoperative diagnostic tools, most parathyroid carcinomas are detected incidentally and postoperatively, during the routine examination of surgical specimens $(1,2,8,11,12,15,17,24-26)$. Thus, all parathyroid gland(s) excised for hyperparathyroidism should be assessed carefully for malignancy. In patients with an unanticipated diagnosis of parathyroid carcinoma, re-operation may be warranted for disease control $(1,2,8,11,12,15,17,24-26)$. While most cases occur sporadically, a significant portion (at least 15\%) can present with germline CDC73/HRPT2 mutations $(2,4,8,27)$. Therefore, genetic testing should be offered to all patients with parathyroid cancer, given its important implications for affected patients and their family members $(2,4,8,11,27,28)$. This review provides an update on the current knowledge of parathyroid carcinomas and highlights the clinicopathological correlates of this rare disease.
Correspondence: Özgür METE

200 Elizabeth Street, 11th Floor, University Health Network, Department of Pathology, TORONTO, ON, M5G 2C4, CANADA

E-mail: ozgur.mete2@uhn.ca Phone: +1 4163403004 


\section{CLINICAL AND BIOCHEMICAL FEATURES}

Clinically, parathyroid carcinoma can occur at any age, with a peak in the fifth decade of life $(1,8-10,29-31)$. It occurs with equal frequency in both sexes, in contrast to the female predominance reported in parathyroid adenomas (1,8$11,25,29,30,32)$. Although the distinction between benign and malignant parathyroid disease remains challenging at the clinical level, certain clinical features can raise a physician's suspicion for an underlying malignancy (Table I) $(1,8-11,25,29,30,32)$. These findings will be highlighted here.

Most parathyroid carcinomas (>90\%) secrete excess parathyroid hormone (PTH). Commonly reported symptoms relate to overt hyperparathyroidism, including renal (nephrolithiasis, nephrocalcinosis), skeletal (bone pain, osteopenia), and neurocognitive involvement (anxiety, depression) (1,4,8-10,19,29,33-35). In the past, both benign and malignant parathyroid disease would present symptomatically in affected patients $(1,4,8-10,19,29,30,33-37)$. However, with the advance of routine serum calcium testing, the majority of patients with benign hyperparathyroidism are now diagnosed incidentally and asymtomatically $(1,4,8-10,19,29,30,33-$ 37). In other terms, the presence of the presence of overt renal and skeletal involvement is unusual in the modern presentation of benign parathyroid disease and should alert a clinician to exclude an underlying malignancy (1,4,8-10,19,29,30,33-38). Other clinical findings, which are worrisome but non-specific for parathyroid carcinoma, include a palpable neck mass, concomitant jaw tumor,

Table I: Risk factors for parathyroid carcinoma

\begin{tabular}{|l|}
\hline $\begin{array}{l}\text { Intraoperative suspicion of local invasion and/or regional } \\
\text { metastasis }\end{array}$ \\
\hline Albumin-corrected calcium levels $>3 \mathrm{mmol} / \mathrm{L}^{\star}$ \\
\hline $3^{\text {rd}} / 2^{\text {nd }}$ generation PTH assay ratio $>1^{\star}$ \\
\hline Palpable neck mass (lesion $>3 \mathrm{~cm})^{*}$ \\
\hline Infiltration and/or calcifications on neck ultrasound \\
\hline $\begin{array}{l}\text { Suspicion of metastatic disease on sestamibi and/or CT } \\
\text { scan }\end{array}$ \\
\hline PTH $>3$ times the upper limit of normal \\
\hline Significant bone and/or kidney involvement \\
\hline Positive personal or family history (HPT-JT) \\
\hline Concomitant jaw tumor \\
\hline Hoarseness and/or neck pain \\
* Indicates high-risk features that may warrant a referral to an endocrine \\
surgeon. PTH: Parathyroid hormone, HPT-JT: Hyperparathyroidism- \\
jaw tumor syndrome, MEN: Multiple endocrine neoplasia syndrome.
\end{tabular}

neck pain and hoarseness $(1,8,10,11,39,40)$. A personal or family history of hypercalcemia and/or genetic syndromes (hyperparathyroidism-jaw tumor syndrome, multiple endocrine neoplasia syndrome and other familial parathyroid diseases) should also alert the physician $(1,8$ $11,28,39-42)$. Rarely, patients with parathyroid carcinoma may present in a state of life-threatening hypercalcemia, with renal failure, cardiac arrhythmia, and/or neurological involvement (coma) (1,8-11,28,39-42).

Biochemically, parathyroid carcinomas tend to present with severe hypercalcemia (albumin-corrected calcium levels $>3.0 \mathrm{mmol} / \mathrm{L}$ ) as a result of overt hyperparathyroidism (PTH levels $>3$ times the upper limit of normal) $(1,8,10,15,29,43)$. In contrast, benign parathyroid disease generally behave more indolently, with mild hypercalcemia (within $1 \mathrm{mg} / \mathrm{dL}$ of normal) and mild-moderate PTH levels, with the exception of large parathyroid adenomas and familial syndromes associated with more florid phenotype (8-10,30,38,42,44-49). Furthermore, secondary hyperparathyroidism can present with similar features and should be excluded, either clinically (history of lithium/thiazide intake, gastrointestinal disease/calcium malabsorption) or biochemically (presence of kidney disease, vitamin D deficiency, hypocalcemia) $(9,10,50)$. Recently, some investigators described a promising method by which a 3rd-generation to 2nd-generation PTH ratio $>1$ can help predict whether a parathyroid tumor is more likely to be malignant in the preoperative setting (sensitivity: 75-82\%; specificity: 97-98\%) (1,8,24,51-54). Although this technique has not been widely adopted at this time, it has been proposed on the basis that parathyroid carcinoma tends to overproduce amino-PTH, which is recognized by 3rd-generation but not 2nd-generation PTH assays (1,8,24,51-55). Rarely, "non-functioning" parathyroid carcinomas have also been described in less than $10 \%$ of cases $(8,11,26,35,56)$.

\section{RADIOLOGICAL FINDINGS}

In addition to clinical and biochemical information, certain radiological features can help distinguish benign from malignant parathyroid disease in the preoperative setting (1,8,21,33,57-60). However, in the absence of unequivocal metastatic disease, the decision to pursue more radical surgery on clinical suspicion alone remains controversial $(1,8)$. Nonetheless, in all patients with primary hyperparathyroidism, radiological investigations is warranted to assess the extent of disease for treatment planning $(9,10,21,30,61)$. In particular, extra-parathyroid imaging, comprising of renal ultrasonography and dualenergy X-ray absorptiometry, is used to assess for PTH- 
related renal disease (nephrolithiasis, nephrocalcinosis) and bone disease (decreased bone density), as these findings may warrant surgical intervention even in the absence of clinical symptoms $(9,10,21,30,38,61,62)$.

Neck ultrasonography is a non-invasive and relatively inexpensive tool that should be considered in all patients with overt hyperparathyroidism $(1,8,33,57-60,63)$. Sonographic evidence of infiltration and/or calcification is strongly associated with parathyroid malignancy, whereas the absence of suspicious vascularity, presence of a thick capsule and heterogeneity within the parathyroid glands is more in keeping with benign parathyroid disease $(1,8,33,57,59)$. The recent development and adoption of 99technetium-labelled sestamibi (99mTc-sestamibi) scintigraphy has enhanced our ability to distinguish between single-gland and multigland parathyroid disease (1,8,21,30,33,57-60,64-68). Increased and prolonged uptake of sestamibi is generally observed in abnormally "hyperfunctioning" parathyroid tissue (1,8,21,30,33,57-60,64-68). When compared to conventional imaging modalities, the sestamibi scan has the advantage of localizing ectopic hyperfunctioning parathyroid tissue; if present, this finding should prompt the physician to consider the possibility of a metastatic parathyroid carcinoma $(1,8,10,15,21,30,33,57-60,64-68)$. Although not routine, CT scan of the neck and chest may also be indicated in some cases to assess for disseminated disease $(1,8,39)$.

\section{HISTOPATHOLOGICAL FEATURES}

Given the current lack of specific preoperative diagnostic tools, parathyroid carcinomas are frequently diagnosed during the routine examination of parathyroidectomy specimens $(1,7,15,17,33,69)$. Therefore, all parathyroid gland(s) resected for primary hyperparathyroidism should be carefully assessed for malignancy, which can occur in $<1-5 \%$ of patients $(1,8,11,14,15,25,31,33,39)$. Accurate recognition of parathyroid carcinoma is critical to guide treatment decision making (see section "Treatment and Prognosis") $(1,7,8,15,33)$. Other pathological correlates in primary hyperparathyroidism include parathyroid adenoma (80-85\%) and hyperplasia (10-15\%) (11,14,25,32,44,70,71). Abnormal proliferation of parenchymal cells typically results in grossly enlarged cellular gland(s), characterized by increase in weight $(>40-60 \mathrm{mg})$ and size $(>6-8 \mathrm{~mm})$ $(11,13,14,26,32,44,70,72-74)$. Rapid intraoperative assay is extremely helpful in confirming the complete removal of abnormal "hyperfunctioning" parathyroid tissue (demonstrated by $>50 \%$ decrease in circulating PTH level 10-15 min after surgical excision), and can help distinguish between single-gland and multi-gland disease (10,11,21,22,75-77). Both parathyroid adenomas and carcinomas present as uniglandular parathyroid proliferations $(11,13,14,26,32,44,70,72,73)$. Thus, at the time of intraoperative consultation, the distinction between parathyroid adenoma and carcinoma is often difficult or even impossible, if the tumor does not show grossly evident invasion into surrounding organs $(1,8,11,14,17,19,73)$. Since the latter is generally identified by the surgeon, the role of intraoperative consultation is often limited.

In comparison to parathyroid adenomas, parathyroid carcinomas tend to be relatively large and bulky (mean diameter of $3.4 \mathrm{~cm}$ and weight of $19.15 \mathrm{~g}$ ) (15), with variable degrees of fibrosis and irregular borders $(1,11,13,14$, $26,44,70,72,73,78,79)$. Common morphological findings include broad fibrous bands, necrosis and solid growth pattern (Figure 1). The presence of increased mitotic activity, atypical mitoses and nuclear atypia should raise the suspicion for an underlying malignancy (Table II) $(11,13,14,26,44,70,72,73)$. However, it should be noted that not all parathyroid carcinomas present these features, and the identification of these findings also is not diagnostic for malignancy $(11,13,14,26,44,70,72,73)$. For instance, a variety of conditions can be associated with broad bandforming fibrosis $(11,26,70,72,73)$. Similar to artifacts occurring after fine-needle aspiration biopsy (FNAB) of the thyroid gland, patients with a previous manipulation of the parathyroid glands (FNAB for preoperative cytological assessment or PTH measurement) may show worrisome histological alterations including fibrous bands with or without hemosiderin deposits (Figure 2A) (80). Similar changes have also been described in individuals with primary hyperparathyroidism that underwent therapeutic ethanol injection (26,81). Moreover, band-forming fibrosis

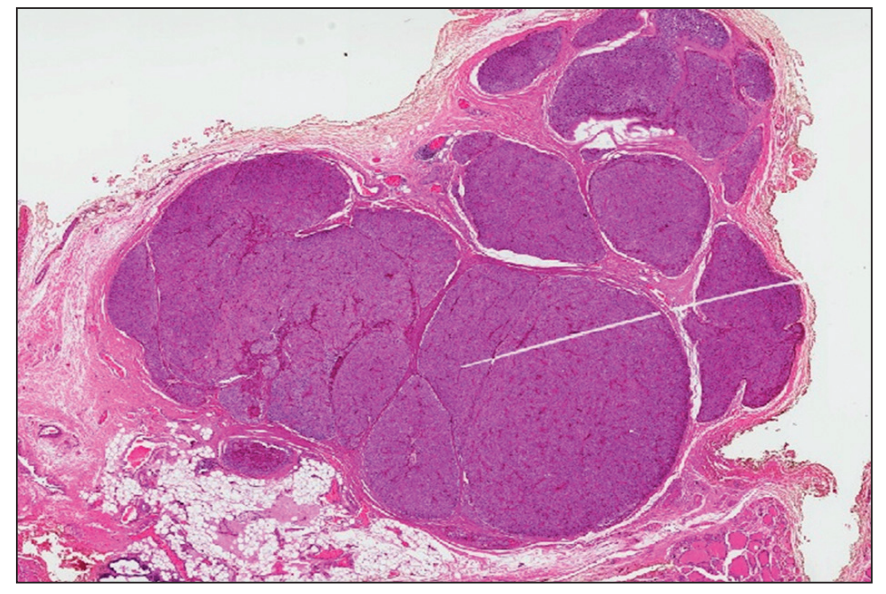

Figure 1: Broad fibrous bands, solid growth and infiltrative growth are common morphologic features of parathyroid carcinomas. However, not all parathyroid carcinomas present these features. 
Table II: Diagnostic features of parathyroid carcinoma

\begin{tabular}{|c|c|}
\hline $\begin{array}{l}\text { Diagnostic histopat } \\
\text { (if } \geq 1 \text { feature is pre }\end{array}$ & ical features \\
\hline Unequivocal vascula & sion \\
\hline Perineural invasion & \\
\hline Gross invasion into & nt anatomic structures \\
\hline Metastasis & \\
\hline $\begin{array}{l}\text { Worrisome histopa } \\
\text { (non-diagnostic) }\end{array}$ & ical features \\
\hline Necrosis $^{\star}$ & \\
\hline Increased mitotic ac & $>5 / 50 \mathrm{HPF})^{\star}$ \\
\hline Macronucleoli* $^{*}$ & \\
\hline Atypical mitoses & \\
\hline Nuclear atypia & \\
\hline Solid growth pattern & \\
\hline Broad fibrous bands & \\
\hline $\begin{array}{l}\text { Ancillary biomarke } \\
\text { carcinoma in borde }\end{array}$ & $\begin{array}{l}\text { support a diagnosis of } \\
\text { ases) }\end{array}$ \\
\hline Parafibromin $(-)^{* *}$ & PGP9.5 (+) \\
\hline $\mathrm{Rb}(-)$ & Galectin-3 (+) \\
\hline p27 (-) & p53 (+) \\
\hline Bcl-2a (-) & MIB-1 (Ki67) >5\% \\
\hline APC (-) & \\
\hline $\mathrm{mdm} 2(-)$ & \\
\hline
\end{tabular}

can occur in parathyroid proliferations from patients with MEN 1 or MEN 4 syndrome, lithium intake or chronic renal failure-related parathyroid hyperplasia (Figure 2B), parathyroiditis and large adenomas with spontaneous degeneration $(11,26,44,70,72,73,82)$. Some experts have proposed a triad of high-risk histopathological features (foci of coagulative necrosis, macronucleoli and mitotic activity $>5 / 50$ high-power fields) to help select tumors which are more prone to malignant behavior (Figure 3) $(11,74,83)$. However, increased mitotic activity, and lesional cells within a thickened fibrous capsule can also be identified in multiglandular parathyroid disease $(11,26,70,72,73,79)$. Necrosis can also occur in a parathyroid proliferation with a previous biopsy or injection, especially in those with predominant oncocytic cytomorphology $(11,26,70,72,73,83)$. It is unfortunate that despite the importance of clinicopathological correlation, many pathologists are still faced with diagnosing a parathyroid lesion in the absence of relevant clinical information $(73,84)$.
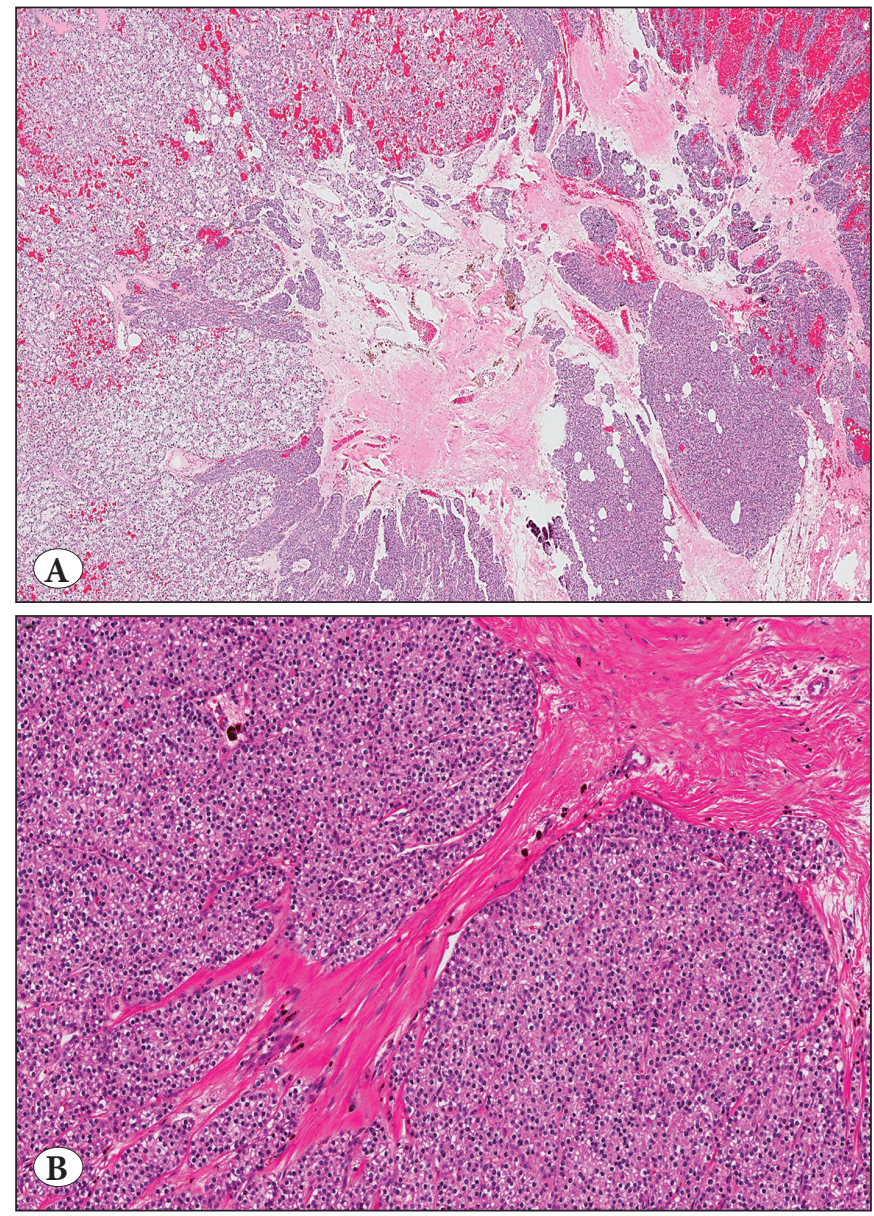

Figure 2: A) Fibrous bands are not specific to parathyroid carcinoma and can be identified in benign parathyroid proliferations following previous FNA biopsy (either for cytological assessment or PTH measurements) and B) in patients with chronic renal failurerelated parathyroid hyperplasia.

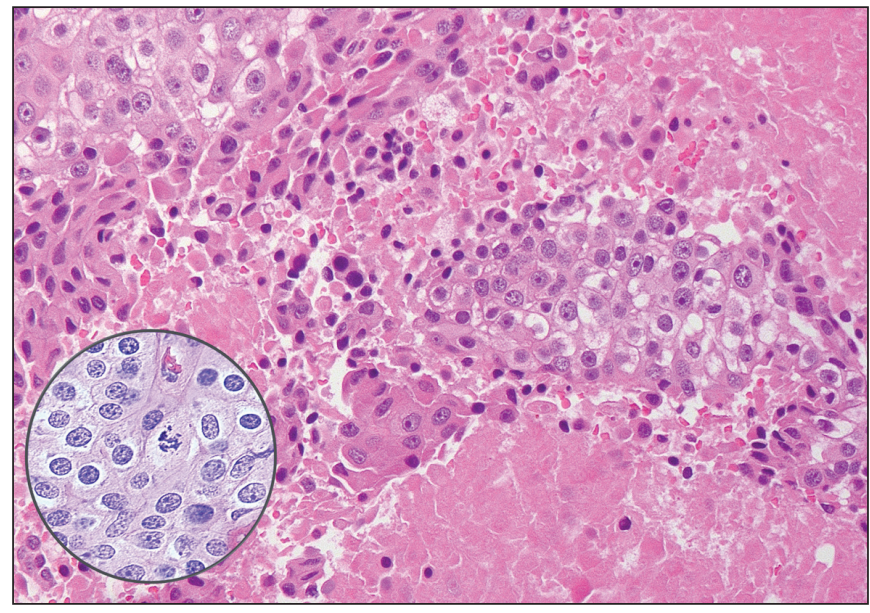

Figure 3: Triad of high risk histopathological features: Foci of coagulative necrosis, prominent macronucleoli, and mitotic activity $>5 / 50$ high-power fields. 
Practicing pathologists should recognize the significant overlap in the cytomorphological features of parathyroid carcinomas and some benign parathyroid proliferations (adenoma and hyperplasia) $(11,12,26,70,72,73,83)$. Therefore, a histological diagnosis of parathyroid carcinoma should only be rendered when a parathyroid neoplasm shows any of the following features: a) vascular invasion (Figure 4A), b) perineural invasion, c) invasion into the adjacent anatomic structures (Figure $4 \mathrm{~B}$ ) and d) metastasis (Table II) $(11,12,15,26,35,44,70,72,73,79,83,85,86)$. It is important to note that not all parathyroid carcinomas present with widely invasive growth and high grade proliferative changes $(11,15,26,70,85)$ However, many of these parathyroid carcinomas simulating adenomas can be distinguished at the morphologic examination by the accurate identification of unequivocal angioinvasion, characterized by the presence of tumor cells invading through a vessel wall and intravascular tumor cells admixed with thrombus (Figure 4A) $(11,12,15,70,73,85,86)$.

As a reflection of the diagnostic challenges associated with some borderline parathyroid proliferations, the $2004 \mathrm{WHO}$
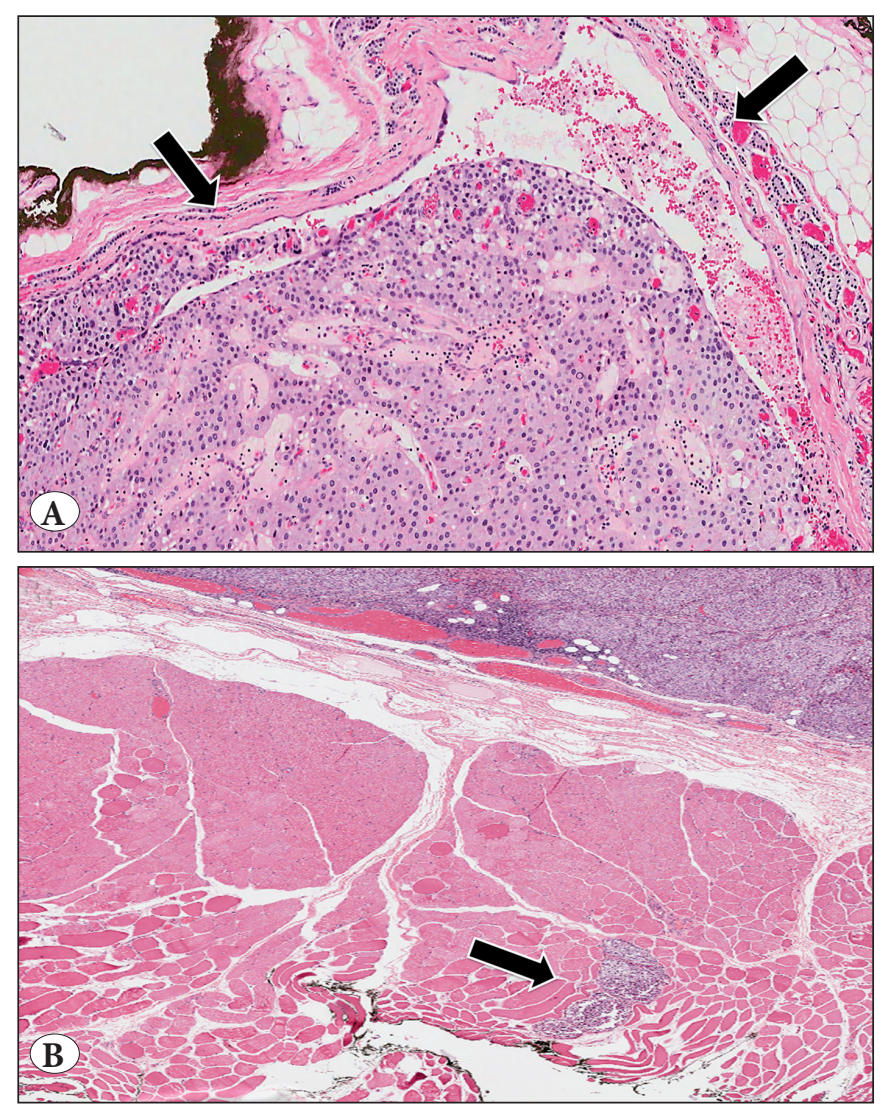

Figure 4: The diagnosis of parathyroid carcinoma is rendered histologically when a parathyroid tumor shows unequivocal evidence of vascular invasion (A), perineural invasion, invasion into the surrounding tissues (B), and metastasis. classification defined a category of "atypical parathyroid adenomas", representing parathyroid neoplasms without unequivocal signs of vascular or capsular invasion, but with some morphological features suspicious for parathyroid carcinomas, including broad fibrous bands with or without hemosiderin deposits, mitoses, and neoplastic cell groups in a thickened fibrous capsule $(11,12,28,79,83,87-90)$. This controversial diagnostic category is almost non-existent in modern practices after clarifying relevant clinical information (e.g. underlying hyperplasia, MEN1 syndrome, medication history, etc..), applying the rigid criteria to identify vascular invasion, and using ancillary tools (8, $11,12,27,28,55,73,85,88,89,91)$. In this specific subgroup, recently discovered biomarkers through molecular pathology have enhanced our ability to differentiate parathyroid carcinomas from adenomas with atypical features $(8,11,12,27,55,73,85,88,89,91)$. These tools with be discussed in the subsequent section. In summary, "atypical parathyroid adenomas" encompass both benign parathyroid proliferations with worrisome reactive changes, as well as some parathyroid carcinomas with insufficient diagnostic features at the morphologic level $(11,12,73,85,87-89)$.

\section{ANCILLARY BIOMARKERS}

Many experts speculate that the concept of "atypical parathyroid adenoma" stems from the limitations of the histopathological examination $(11,12,26,79,83)$. With the discovery of novel biomarkers and molecular biological techniques, surgical pathologists are increasingly able to better classify these lesions in their appropriate categories (either benign or malignant) to optimize patient care (2,8,11,12,27,28,55,85,88,89,91-98). Methylation profile of parathyroid tumors has been shown to distinguish parathyroid adenoma from parathyroid carcinoma (99-103). Moreover, over $70 \%$ of sporadic parathyroid carcinomas have been linked to sporadic mutations in the CDC73/ HRPT2 gene $(2,28,92,95,104,105)$. While most laboratories are far away to adopt these molecular testing as a part of their routine patient care, the use of immunohistochemical biomarkers has been shown to be useful to reach a definite diagnosis in most cases to enhance patient care $(2,8,11,12,27,28,55,85,88,89,91-98)$. Based on the current literature, an immunohistochemical signature comprising of loss-of-expression of parafibromin, retinoblastoma protein (Rb), p27, Bcl-2a, mdm-2, and APC, along with positivity for galectin-3, overexpression of p53, and increased MIB1 (Ki67) proliferation index $(>5 \%)$ has been suggested to confirm a diagnosis of malignancy in a parathyroid tumor with worrisome histopathological features (Figure 5A-F) (Table II) $(2,8,11,12,27,28,55,73,85,88,89,91-98)$. It should 


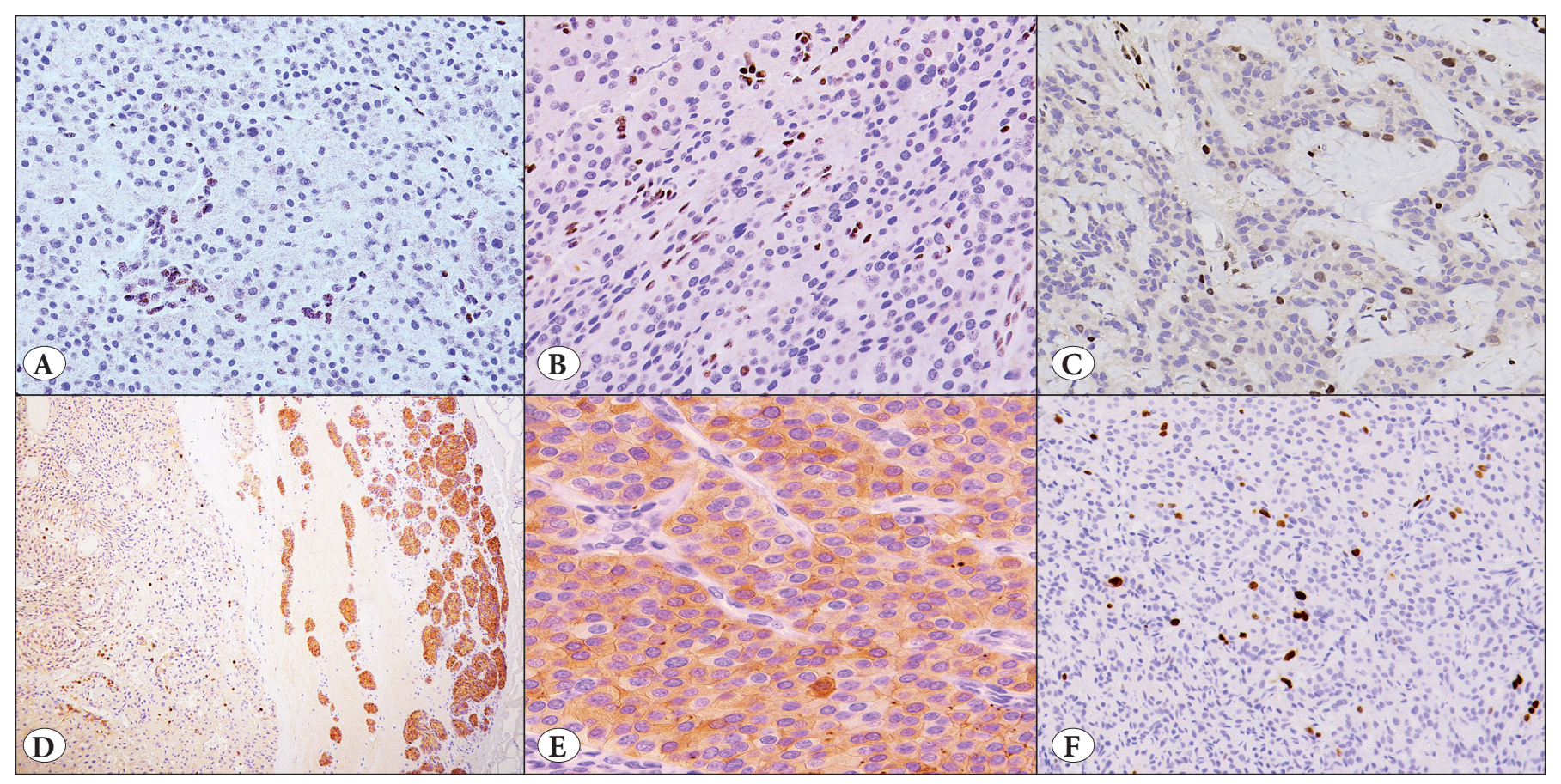

Figure 5: Biomarkers of parathyroid carcinoma. Global loss of nuclear and nucleolar parafibromin expression is regarded a reliable diagnostic marker of parathyroid carcinoma (A). Parathyroid carcinomas can also show loss of Rb (B), p27 (C), and APC (D). In solitary gland disease, the presence of galectin-3 expression (E) along with a MIB-1 labeling index $>5 \%$ (F) can be identified in malignancy.

be noted that these new biomarkers were derived from recent genetic studies on the pathogenesis of parathyroid carcinoma, which will be discussed in the subsequent section ("Pathogenesis and molecular features"). In our experience, parafibromin, galectin- 3 , and bcl- $2 \mathrm{a}$ are the most helpful ancillary biomarkers $(73,85)$. In addition to serving a diagnostic role in tumors with complete loss of parafibromin (in the appropriate clinical and pathological setting), loss of parafibromin expression appears to be a prognostic biomarker for parathyroid carcinomas $(1,27,2$ $8,73,85,88,91,92,94,96,106,107)$. Furthermore, it can help select high-risk patients for genetic testing of germline CDC73/HRPT2 $(1,28,89)$. Prognostically, when compared to those with intact parafibromin expression, parathyroid carcinomas with loss of parafibromin expression have a significantly higher risk of disease recurrence, a decreased 5-year survival of 59\% and a decreased 10-year survival of $23 \%(28,89,106)$. In light of these findings, some groups suggest that it may be reasonable to perform routine parafibromin biomarker assessment in all cases of pathologically confirmed parathyroid carcinomas $(1,28,73,85,94,106)$.

In addition to primary malignancies of the parathyroid (parathyroid carcinoma), secondary (metastatic or infiltrating) malignant neoplasms from various organs can also deposit in the parathyroid glands (35). Very recently, Shifrin et al. highlighted the importance of considering metastatic disease in the parathyroid glands as these are often overlooked and discovered incidentally at autopsy or during surgery for primary hyperparathyroidism $(13,14,35,108-114)$. For instance, direct extension from thyroid carcinomainto the parathyroid glands may occur in up to $4 \%$ of patients with thyroid carcinoma $(35,108,110)$. Most parathyroid glands are located within the thyroid pseudocapsule or within the thyroid gland, and intrathyroidal parathyroid carcinomas can mimic a variety of tumors including medullary thyroid carcinoma, thyroid paraganglioma, secondary (metastatic) neuroendocrine carcinoma and poorly differentiated thyroid carcinoma. In challenging cases, immunohistochemistry can confirm the origin of parathyroid $(11,13,44,70,73)$. Positivity for PTH (strong cytoplasmic staining in chief cells), low molecular weight cytokeratins (CK8, CK18, CK19) and chromogranin-A are helpful in supporting the primary parathyroid origin of the tumor $(26,32,79)$. One has to remember that PTH or PTH-related peptide can also be expressed in other neuroendocrine tumors (73,115-117). Therefore, application of transcription factors (e.g. GCM2, GATA-3) expressed in parathyroid tissue can support parathyroid origin (Figure 6), along with a positive PTH expression (73,118-122). 


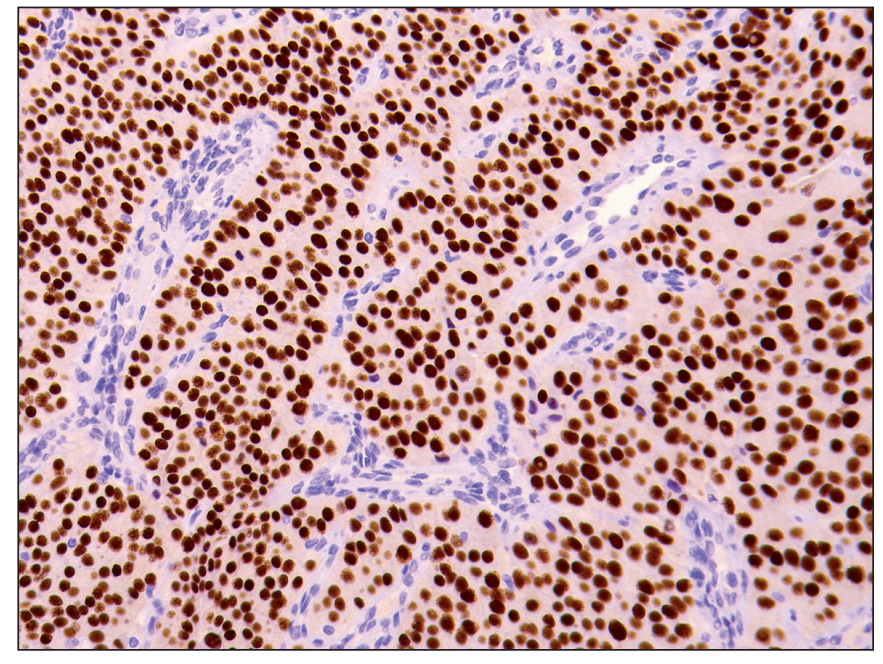

Figure 6: Confirmation of parathyroid origin. While most laboratories use PTH immunohistochemistry to distinguish a parathyroid origin, the demonstration of positivity for GATA-3 or GCM-2 also supports the origin of parathyroid when dealing with a PTH-producing neuroendocrine carcinoma.

\section{PATHOGENESIS AND MOLECULAR BIOLOGY}

While the etiology of parathyroid carcinoma remains largely unknown, it appears to be a complex interaction between environmental factors, causing sporadic alterations, and inherited genetic predispositions $(1,2,8,28,41,55,73,85,100)$. Contrary to other solid tumors, a definite hyperplasia-adenoma-carcinoma progression sequence has not been established in parathyroid tissue $(11,12,26,41,100,123-125)$. The lack of convincing data is largely attributed to the extreme rarity of parathyroid carcinomas $(1,11,33,73,123)$. However, if an adenoma-carcinoma progression truly prevailed, this would offer a valid explanation as to why parathyroid carcinomas are so uncommon, why parathyroid carcinomas are so uncommon, because this would suggest that most parathyroid tumors are detected and resected prior to becoming malignant, at the benign "hyperfunctioning" adenoma stage. This hypothesis is further supported by the fact that most parathyroid carcinomas ( $>90 \%)$ produce excess PTH, suggesting that hormonal oversecretion typically occurs simultaneous or prior to the development of malignancy $(11,26,56)$. Nonetheless, a parathyroid hyperplasianeoplasia progression sequence has been described in some patients with refractory secondary hyperparathyroidism (tertiary hyperparathyroidism) and/or familial disease (1, $2,8,11,12,25,26,28,31,33,73,86,100,106,126,127)$. The main pathways involved in parathyroid tumorigenesis, including aberrant CaSR, cyclin D1 and Wnt/ $\beta$-catenin signalling, as well as their associated alterations will be highlighted here $(55,100,128)$.

\section{CaSR Signalling and PTH Oversecretion}

Calcium sensing-receptor (CaSR) signalling plays a critical role in the regulation of parathyroid hormone (PTH) secretion by parathyroid chief cells $(9,100,129-132,132)$. Aberrant inactivation of CaSR signalling has been linked to proliferative parathyroid disorders, including hyperplasia and neoplasia $(50,55,100,127,132-145)$. For instance, patients with tertiary hyperparathyroidism tend to present with multifocal clonal proliferations (nodules/adenomas) in a background of polyclonal diffuse parathyroid hyperplasia $(11,26,50,55,100,136,138,140,143,144)$. This neoplastic transformation has been linked to deregulated CaSR signalling, as demonstrated by loss-of-expression of calcium sensing-receptor (CaSR) and vitamin D receptor (VDR) $\quad(11,26,50,55,100,136,138,140,143,144)$. Deriving from studies of other organs, inactivation of CaSR is thought to induce cyclin D1 and possibly Wnt/ $\beta$-catenin signalling (55,137,146-148). Furthermore, aberrant CaSR signalling has been reported in a large subset of parathyroid adenomas (50,55,100,127,132-145). Rare parathyroid carcinomas have also been reported with deregulated CaSR signalling from prolonged secondary/tertiary hyperparathyroidism $(1,8,11,26,33,73,86,100,126,127,149)$. Although the exact mechanism underlying aberrant CaSR signalling remains unknown, genetic and epigenetic mechanisms underlying CaSR and VDR genes are infrequent in parathyroid tumors $(55,100,133,137,146-148)$. These findings suggest that there are likely undiscovered mutations causing aberrant CaSR signalling, found in a large subset of parathyroid tumors $(11,26,50,55,100,136-138,140,143,144)$.

\section{Cyclin D1 Signalling and Parathyroid Tumorigenesis}

In contrast to CaSR signalling, cyclin D1 signalling is involved in cell cycle progression $(41,55,100,131,132,150$ 153). Aberrant activation of cyclin D1 signalling has been well described in a large subset of parathyroid tumors, implicating altered CCND1/PRAD1, CDKIs, and ZFX genes (2, 11, 28, 41, 55, 100, 131, 132, 150-155). CCND1/PRAD1 (11q13) is a proto-oncogene encoding the cyclin D1 protein, a holoenzyme thought to inactivate the tumor-suppressor retinoblastoma protein $(\mathrm{Rb})(41,55,100,131,132,150$ $153,156)$. Somatic activating mutations of CCND1/PRAD1 with overexpression of cyclin D1 protein has been reported in up to $40 \%$ of parathyroid adenomas, and up to $90 \%$ of parathyroid carcinomas $(11,32,41,55,100,131,132,145,150$ $153,157,158)$. In order to clarify the mechanisms underlying a putative progression from benign to malignant parathyroid tumors, Zhao et al. compared 7 parathyroid carcinomas to 14 adenomas; they reported a gain in copy number of the CCND1 gene in carcinomas, and showed a 
significant increase in CCND1 gene expression both at the mRNA level and immunohistochemically (153). While this study has While this study has limitations limitation, to our knowledge it is one of the first of its kind to explore copy number alterations in cyclin D1 signalling and its putative role in parathyroid adenoma-carcinoma progression.

Concurrent to the discovery of the parathyroid oncoprotein cyclin D1, its binding partners in cell cycle regulation, cyclin-dependent inhibitors (CDKIs), were also found to be altered in a subset of patients with hyperparathyroidism $(11,32,41,55,85,100,131,132,159-161)$. Both germline and somatic inactivating mutations in CDKI-encoding genes (CDKN1B encoding p27kip1 protein, CDKN1A encoding p21Cip1, CDKN2B encoding p15Ink4b, CDKN2C encoding p18Ink4c, and CDKN2D encoding p19) were identified in parathyroid neoplasms $(11,32,41,55,85,100,131,132,159$ 162). Of these, the tumor suppressor function of $C D K N 1 B$ (12p13.1) and its gene product, p27kip1, have been well documented: germline inactivating mutations of $C D K N 1 B$ gives rise to multiple endocrine neoplasia type 4 syndrome (MEN-4, also known as "MEN-X"), whereas somatic inactivating mutations in $C D K N 1 B$ were reported in some parathyroid tumors, with loss of p27 protein expression $(11,32,41,55,85,93,100,131,159,162)$. Moreover, immunohistochemical studies have reported a 3-to-4 fold decrease of p27 expression in parathyroid carcinomas in comparison to adenomas $(11,85,93,159)$. Epigenetic alterations of CDKIs (CDKN2A, CDKN2B) have also been reported in parathyroid tumors $(99,100,103,128,163)$. Recently, recurrent mutation of ZFX, a putative protooncogene thought to be a downstream target of cyclin D1, has also been found in a subset of parathyroid adenomas ( 5\%) (154,155). Activating mutations in RET protooncogene (10q11.2), a putative inducer of cyclin D1 signalling, is also described in some parathyroid tumors from patients with multiple endocrine neoplasia type 2A (MEN-2A) (11,100,124,145,164-166).

\section{Wnt/ $\beta$-Catenin Signalling and Parathyroid Tumorigenesis}

Deregulation of $\mathrm{Wnt} / \beta$-catenin signalling is an important tumorigenesis pathway in many organs, including the parathyroid glands, by inducing cyclin D1 overexpression $(55,99,100,128,145,167-171)$. Several genetic and epigenetic alterations causing excess $\mathrm{Wnt} / \beta$-catenin signalling have been uncovered in parathyroid neoplasms, implicating MEN1, CTNNB1, SFRP1, SFRP2, SFRP4, GSK3B, and $A P C$ genes $(55,88,99,100,128,145,167-169,172-177)$. Of these, inactivation of MEN1 (11q13) and its gene product, menin, is the most frequently described alteration, reported in $20-40 \%$ of parathyroid adenomas and rare carcinomas
$(11,100,145,178-181)$. Menin protein is thought to play a tumor suppressor role by preventing nuclear translocation of $\beta$-catenin, thereby decreasing $\mathrm{Wnt} / \beta$-catenin signalling $(182,183)$. Mutation of CTNNB1 has also been described in $2-5 \%$ of parathyroid adenomas, resulting in aberrant accumulation of $\beta$-catenin in tumor cells, although it remains unclear whether this step requires additional epigenetic alterations $(55,100,172,176,176,177)$. Furthermore, hypermethylation of secreted fizzled-related protein (SFRP)encoding genes (SFRP1, SFRP2, SFRP4; thought to serve tumor suppressor functions in Wnt/ $\beta$-catenin signalling) have been reported in a subset of parathyroid carcinomas $(99,100,103,128)$. Loss-of-expression of glycogen synthase kinase $3-\beta$ (GSK3B), a putative tumor suppressor protein in Wnt/ $\beta$-catenin signalling, has been reported in both adenomas and carcinomas, although the exact genetic mechanism remains unclear (169). Recently, the role of the tumor suppressor adenomatous polyposis coli (APC) gene, which is inactivated in the cancer predisposition familial adenomatous polyposis syndrome (FAP), was also explored in the parathyroid glands $(88,99,100,103,128,169,184)$. Loss of its gene product, APC protein, was reported in parathyroid carcinomas (Figure 5D), whereas it is generally preserved in adenomas (88). While both adenomas and carcinomas often show hypermethylation of promoter $1 \mathrm{~A}$ region of the $A P C$ gene; the preserved expression of APC protein and APC mRNA in adenomas could be partially explained by increased expression of promoter $1 \mathrm{~B}$ region of the APC gene in parathyroid adenomas $(88,100,168,184)$. These findings show the complex interaction between genetic and epigenetic alterations causing excess Wnt/ $\beta$ catenin signalling in a putative adenoma-carcinoma progression sequence in the parathyroid glands $(55,88,99,100,128,145,167-170,184)$.

\section{Parafibromin and Parathyroid Carcinoma}

In addition to the previously described alterations in CaSR, cyclin D1 and Wnt/ $\beta$-catenin signalling, aberrant parafibromin expression is commonly described in parathyroid neoplasms, specifically parathyroid carcinomas $(2,11,12,28,32,73,85,88,89,91,92,94-96,100,106)$. When used in the appropriate clinical and histopathological setting, parafibromin is currently the most specific biomarker for diagnosis and prognosis of parathyroid carcinoma, and helps stratify high-risk patients for genetic testing $(11,12,28,32,73,88,89,91,92,94-96)$. Parafibromin protein, encoded by the CDC73/HRPT2 gene (1q31.2), is thought to serve a critical tumor suppressor role in parathyroid tissue through several molecular mechanisms, by interacting with the polymerase associated factor 1 (PAF1) complex in histone 
ubiquitination/methylation, mediating gene transcription, inducing apoptosis, inhibiting cyclin D1 signalling, regulating Wnt $/ \beta$-catenin signalling and growth factor gene transcription $(2,11,12,28,32,73,85,88,89,91,92,94$ $96,100,106)$. Given its central role in regulating cellular function, it is unsurprising that bi-allelic inactivation of CDC73/HRPT2 gene and complete loss of parafibromin expression almost inevitably leads to parathyroid cancer (Figure 5A) $(2,11,12,28,32,88,89,91,92,94-96,100,106)$. In particular, its role in a hyperplasia-neoplasia (adenomacarcinoma) progression sequencehas been well documented in patients with an inherited inactivated copy of CDC73/ HRPT2 (hyperparathyroidism-jaw tumor syndrome; HPTJT or isolated familial hyperparathyroidism), who develop parathyroid carcinomas in the setting of pre-existing "cystic" adenomas/nodular hyperplasia in up to $20 \%$ of cases $(2,11,12,28,32,88,89,91,92,94-96,100,106,185)$. Although bi-allelic inactivation of CDC73/HRPT2 (either due to inherited/somatic, or somatic/somatic "hit") and complete loss of parafibromin expression is almost always seen in parathyroid carcinomas, partial loss of parafibromin expression (single allelic inactivation of CDC73/HRPT2) is less equivocal and may occur in both benign and malignant parathyroid tumors, $(2,11,12,27,28,32,89,91,92,95,96,100,104,105,185-187)$ hence the critical role of confirming each diagnosis by integrating clinical and histopathological findings, as well as other biomarkers of parathyroid carcinoma $(2,11,12,27,28,32,86,88,89,92,93,97,101,102,180-182)$.

\section{DNA Hypermethylation, MicroRNA Deregulation and Other Molecular Alterations}

Recently, DNA methylome and microRNAome uncovered additional mechanisms underlying parathyroid tumor formation $(99,100,103,128)$. From these studies, substantial evidence emerged showing increased hypermethylation of specific CpG islands in malignant tumors when compared to benign ones, supporting a putative adenoma-carcinoma progression sequence in parathyroid tissue $(99,100,103,128)$. In addition to previously described epigenetic silencing of $A P C$, SFRP and CDKI genes, parathyroid tumors were shown to have aberrant hypermethylation of putative tumor suppressor genes RASSF1A, HIC1, RIZ1, and $W T 1$, with down-regulation of their gene products $(99,100,103,128,188)$. RASSF1A (Ras association domain protein family protein 1$)$ gene $(3 \mathrm{p} 21)$ is thought to serve a tumor suppressor role by inhibiting cyclin D1 expression $(184,189,190)$. HIC1 (17p13.3) also serves a tumor suppressor role, by repressing transcription of histone deacetylase SIRT1 in p53 signalling to preserve genomic stability $(128,188)$. WT1 (Wilms' tumor 1) gene encodes an important tumor suppressing transcription factor in cell growth and differentiation $(99,100,103,128)$. Similarly, RIZ1 (retinoblastoma-interacting zinc finger gene) serves a tumor suppressor function by regulating cell cycle in normal parathyroid tissue $(99,100,103,128,185,191)$.

Aberrant expression of embryonic-related microRNAs was also reported in a series of parathyroid tumors, suggesting that reactivation of embryonic transcription factors may play a role in their pathogenesis $(128,192)$. Recently, the use of whole-exome sequencing shed light on additional mutations in parathyroid carcinomas $(100,164,180,193,194)$. In particular, a recent study of 22 parathyroid carcinomas and 40 parathyroid adenomas revealed recurrent mutations of PRUNE2 in 4/22 (18\%) parathyroid carcinomas and only a single adenoma was found to have rare missense polymorphism of this gene (193). Alterations involving mTOR, MLL2, CDKN2C, THRAP3, PIK3CA, and EZH2 (mediating histone methyltransferase) were also reported in parathyroid carcinomas $(100,164,180,193,194)$.

\section{TREATMENT AND PROGNOSIS}

In recent years, an oncologic surgical approach, comprising of en bloc resection with ipsilateral hemithyroidectomy, has emerged as the treatment of choice in localized parathyroid cancer (Table III) $(1,8,15-17,19,22,39,195-197)$. Although controversial, central neck dissection has also been recommended on the basis that it does not impose significant risk to the patient, since lymph node metastasis at level VI can occur in $\sim 15-30 \%$ of cases $(1,8,15-17,22,39,197)$. Following this approach, the pathological confirmation of R0 resection margins (no cancer cells at margins and/ or $>1 \mathrm{~mm}$ from the edge) confers the highest chance of cure $(1,8,15-18,22,39,197)$. The benefit of adjuvant therapy, including chemotherapy and radiotherapy, remains unclear $(1,8,15,39)$. Some reports have proposed that postoperative radiotherapy may reduce the risk of local recurrence in patients with positive or close surgical margins, although this approach should not replace revision surgery in patients with inadequate resection margins (Table III) $(1,4,8,15-18,22,39,197,198)$.

Although a formal AJCC/UICC TNM staging system for parathyroid cancer has not been established, a recent prognostic classification system has been proposed on the basis of a 2010 study by Schulte and colleagues $(1,7,8,15,17,18,39)$. High-risk patients were defined as having one of the following clinicopathological criteria: vascular invasion, lymph node metastasis or invasion of the trachea, oesophagus or major cervical vessels 
Table III: Prognostic and predictive factors in parathyroid carcinoma

\begin{tabular}{|c|c|}
\hline Type of initial surgery & Clinical considerations \\
\hline $\begin{array}{l}\text { En bloc resection with ipsilateral hemithyroidectomy } \\
+/ \text { - central neck dissection is recommended }\end{array}$ & $\begin{array}{l}\text { Consider revision surgery in unanticipated postoperative } \\
\text { diagnosis of parathyroid carcinoma, to ensure an } \\
\text { appropriate oncologic surgical resection }\end{array}$ \\
\hline \multicolumn{2}{|c|}{ Histopathological features associated with worse prognosis } \\
\hline Positive surgical margins & Consider revision surgery \pm radiotherapy \\
\hline Vascular invasion & Consider close surveillance for recurrence \\
\hline Lymph node and/or distant metastasis & Consider surgical resection of metastases (if feasible) \\
\hline $\begin{array}{l}\text { Invasion of trachea, oesophagus and/or } \\
\text { major cervical vessels }\end{array}$ & Consider close surveillance for recurrence \\
\hline Gross capsular rupture & Consider close surveillance for recurrence \\
\hline \multicolumn{2}{|l|}{ Prognostic markers associated with worse prognosis } \\
\hline Complete loss of parafibromin expression & Genetic counselling and close surveillance for recurrence \\
\hline Persistent PTH assay ratio $>1$ or PTH excess after surgery & $\begin{array}{l}\text { Repeat imaging to localize residual disease } \\
\pm \text { revision surgery (if feasible) }\end{array}$ \\
\hline Germline mutation of HRPT2/CDC73* & Genetic counselling \pm additional investigations for HPT-JT \\
\hline
\end{tabular}

$(1,7,8,15,17,18,39)$. These patients had a significantly increased risk of disease recurrence and $50 \%$ disease-specific mortality at 5 years, compared with no deaths in the low-risk group $(7,8,39)$. In particular, the presence of unequivocal vascular invasion is probably the single most important predictor of distant recurrence or metastasis, and has been proposed by some experts to warrant more aggressive postoperative surveillance and possible systemic therapy in future trials $(1,7,8,18,39,85)$. Conversely, the absence of angioinvasion strongly predicts the absence of distant metastases $(1,7,8,18,39,85)$. In terms of molecular testing, some experts advocate for routine parafibromin testing in all parathyroid carcinomas $(1,11,27,28,92,94,95,106)$. In addition to being a valuable diagnostic marker, there is emerging evidence that complete loss of parafibromin is associated with a worst prognosis in definite parathyroid carcinomas $(28,89,92,106)$. Those with loss of parafibromin expression should also be considered for genetic testing, as patients with germline CDC73/HRPT2 mutations may require closer surveillance and screening for family members (Table III) $(1,2,8,11,27,28,92,94,95,106)$.

In patients with inoperable disease, the prognosis remains poor, as current treatment modalities are largely ineffective $(1,4,8)$. The most common approach pertains to symptom relief through control of $\mathrm{PTH}$-mediated hypercalcemia, which is the main cause of morbidity and mortality in these patients $(1,8)$. Biphosphonates offer short-term relief (up to several months), by inhibiting osteoclastmediated bone resorption $(1,8)$. Recently, denosumab, a monoclonal antibody against "receptor activator activator of nuclear factor $\kappa B$ ligand (RANKL)", has also been used with promising results (199-202). Calcimimetic agents (cinacalcet), allosteric modulators of calcium-sensing receptor (CaSR), have also been shown to reduce calcium levels on a short term basis in patients with inoperative parathyroid cancer (203-207). Rapid treatment with aggressive saline infusion and loop diuretics are required to counter the life-threatening effects of hypercalcemia in hypercalcemic crisis $(1,8)$. Other interventions, including mithramycine, plicamicyn, calcitonin, glucocorticoids, and radiofrequency ablation offer variable benefits $(1,8)$. More recently, immunotherapy has emerged as a promising treatment modality in parathyroid cancer, whereby induction of neutralizing autoantibodies against human PTH significantly improved PTH and calcium levels in some patients with metastatic parathyroid carcinoma (1,8,208-210).

\section{CONCLUSION}

Parathyroid carcinoma is a rare diagnosis with critical implications for affected patients (Table III). Clinical acumen is paramount to ensure early detection and timely treatment to prevent morbid complications of PTH-mediated hypercalcemia. In recent years, an oncologic surgical 
approach has been shown to provide the best outcomes in parathyroid cancer. To this effect, new tools have been developed to enhance our ability to detect these aggressive lesions. Patients with high-risk features of parathyroid malignancy, including severe hypercalcemia (albumincorrected calcium $>3 \mathrm{mmol} / \mathrm{L})$, a palpable neck mass $(>3$ $\mathrm{cm})$, and/or 3rd/2nd generation PTH assay ratio $(>1)$, should be referred to an endocrine surgeon for consideration of more radical surgery. Occasionally, an unanticipated postoperative diagnosis of parathyroid carcinoma may occur, prompting revision surgery to optimize disease control. While most parathyroid carcinomas are diagnosed morphologically by correlating with clinical information, a panel of biomarkers (parafibromin, Rb, p27, Bcl-2a, APC, p53, galectin-3, and MIB-1/Ki67 proliferation index) may be helpful in challenging cases. Genetic testing should be offered to all patients with parathyroid carcinomas, since germline CDC73/HRPT2 mutation can occur in $>15 \%$ of cases. In patients with inoperable disease, the prognosis remains poor and current treatments are largely ineffective. Recent advances in molecular pathology offer promising therapeutic targets implicating cyclin D1, Wnt/ B-catenin and CaSR signalling, which have been found to be deregulated in a significant proportion of parathyroid carcinomas.

\section{CONFLICT OF INTEREST}

The authors have declared no conflict of interest.

\section{REFERENCES}

1. Betea D, Potorac I, Beckers A. Parathyroid carcinoma: Challenges in diagnosis and treatment. Ann Endocrinol (Paris). 2015;76:169-77.

2. Simonds WF. Parathyroid cancer and the CDC73 tumor suppressor gene. Int J Endocr Oncol. 2014;1:59-69.

3. Pasieka JL, Khalil M. Parathyroid Carcinoma. In: Oertli D, Udelsman R, editors. Surgery of the thyroid and parathyroid glands. Berlin Heidelberg:Springer;2012.537-54.

4. Wei $\mathrm{CH}$, Harari A. Parathyroid carcinoma: Update and guidelines for management. Curr Treat Options Oncol. 2012;13:11-23.

5. Arrangoiz R, Ridge JA. Parathyroid Carcinoma. In: Textbook of Uncommon Cancer. In: Raghavan D, Blanke CD, Johnson DH, Moots PL, Reaman GH, Rose PG, Sekeres MA, editors. Hoboken, New Jersey:John Wiley \& Sons, Inc;2012. 201-9.

6. Lee PK, Jarosek SL, Virnig BA, Evasovich M, Tuttle TM. Trends in the incidence and treatment of parathyroid cancer in the United States. Cancer. 2007;109:1736-41.

7. Schulte KM, Gill AJ, Barczynski M, Karakas E, Miyauchi A, Knoefel WT, Lombardi CP, Talat N, Diaz-Cano S, Grant CS. Classification of parathyroid cancer. Ann Surg Oncol. 2012;19:2620-8.
8. Schulte K-M, Talat N. Diagnosis and management of parathyroid cancer. Nat Rev Endocrinol. 2012;8:612-22.

9. Fraser WD. Hyperparathyroidism. Lancet. 2009;374:145-58.

10. Marcocci C, Cetani F. Clinical practice. Primary hyperparathyroidism. N Engl J Med. 2011;365:2389-97.

11. DeLellis RA. Parathyroid tumors and related disorders. Mod Pathol. 2011;24 Suppl 2:S78-93.

12. DeLellis RA. Challenging lesions in the differential diagnosis of endocrine tumors: Parathryoid carcinoma. Endocr Pathol. 2008;19:221-5.

13. LiVolsi VA, Montone KT, Baloch ZN. Parathyroid. Surg Pathol Clin. 2014;7:515-31.

14. Baloch ZW, LiVolsi VA. Pathology of the parathyroid glands in hyperparathyroidism. Semin Diagn Pathol. 2013;30:165-77.

15. Erovic BM, Goldstein DP, Kim D, Mete O, Brierley J, Tsang R, Freeman JL, Asa SL, Rotstein L, Irish JC. Parathyroid cancer: Outcome analysis of 16 patients treated at the Princess Margaret Hospital. Head Neck. 2013;35:35-39.

16. Schulte K-M, Talat N, Miell J, Moniz C, Sinha P, Diaz-Cano S. Lymph node involvement and surgical approach in parathyroid cancer. World J Surg. 2010;34:2611-20.

17. Schulte KM, Talat N, Galata G, Gilbert J, Miell J, Hofbauer LC, Barthel A, Diaz-Cano S, Bornstein SR. Oncologic resection achieving r0 margins improves disease-free survival in parathyroid cancer. Ann Surg Oncol. 2014;21:1891-7.

18. Villar-del-Moral J, Jiménez-García A, Salvador-Egea P, MartosMartínez JM, Nuño-Vázquez-Garza JM, Serradilla-Martín M, Gómez-Palacios A, Moreno-Llorente P, Ortega-Serrano J, de la Quintana-Basarrate A. Prognostic factors and staging systems in parathyroid cancer: A multicenter cohort study. Surgery. 2014;156:1132-44.

19. Dąbrowska A, Tarach J, Zwolak A. Primary hyperparathyroidism due to parathyroid cancer-a diagnostic and management challenge. Endokrynol Pol. 2015;66:150-67.

20. Quinn CE, Healy J, Lebastchi AH, Brown TC, Stein JE, Prasad ML, Callender GG, Carling T, Udelsman R. Modern experience with aggressive parathyroid tumors in a high-volume new England referral center. J Am Coll Surg. 2015;220:1054-62.

21. Udelsman R, Åkerström G, Biagini C, Duh QY, Miccoli P, Niederle $\mathrm{B}$, Tonelli F. The surgical management of asymptomatic primary hyperparathyroidism: proceedings of the Fourth International Workshop. J Clin Endocrinol Metab. 2014;99:3595-606.

22. Van Udelsman B, Udelsman R. Surgery in primary hyperparathyroidism: Extensive personal experience. J Clin Densitom Off J Int Soc Clin Densitom. 2013;16:54-9.

23. Rawat N, Khetan N, Williams DW, Baxter JN. Parathyroid carcinoma. Br J Surg. 2005;92:1345-53.

24. Cavalier E, Betea D, Schleck ML, Gadisseur R, Vroonen L, Delanaye P, Daly AF, Beckers A. The third/second generation PTH assay ratio as a marker for parathyroid carcinoma: Evaluation using an automated platform. J Clin Endocrinol Metab. 2014;99:E453-E457.

25. DeLellis RA, Mazzaglia P, Mangray S. Primary hyperparathyroidism: A current perspective. Arch Pathol Lab Med. 2008;132:1251-62. 
26. DeLellis RA. Tumors of the parathyroid gland. In: Atlas of Tumor Pathology. Vol 6. Washington, DC: Armed Forces Institute of Pathology;1993.

27. Juhlin CC, Höög A. Parafibromin as a diagnostic instrument for parathyroid carcinoma-lone ranger or part of the posse? Int J Endocrinol. 2010;2010:324964.

28. Gill AJ. Understanding the genetic basis of parathyroid carcinoma. Endocr Pathol. 2014;25:30-34.

29. Do Cao C, Aubert S, Trinel C, Odou M-F, Bayaram M, Patey M. Parathyroid carcinoma: Diagnostic criteria, classification, evaluation. Ann Endocrinol (Paris). 2015;76:165-8.

30. Silverberg SJ, Bilezikian JP. The diagnosis and management of asymptomatic primary hyperparathyroidism. Nat Clin Pract Endocrinol Metab. 2006;2:494-503.

31. Marcocci C, Cetani F, Rubin MR, Silverberg SJ, Pinchera A, Bilezikian JP. Parathyroid Carcinoma. J Bone Miner Res. 2008;23:1869-80.

32. Carlson D. Parathyroid pathology: Hyperparathyroidism and parathyroid tumors. Arch Pathol Lab Med. 2010;134:1639-44.

33. Al-Kurd A, Mekel M, Mazeh H. Parathyroid carcinoma. Surg Oncol. 2014;23:107-14.

34. Kassahun WT, Jonas S. Focus on parathyroid carcinoma. Int J Surg Lond Engl. 2011;9:13-9.

35. Shifrin A, LiVolsi V, Shifrin-Douglas S, Zheng M, Erler B, Matulewicz T, Davis J. Primary and metastatic parathyroid malignancies: A rare or underdiagnosed condition? J Clin Endocrinol Metab. 2014;100:E478-81.

36. Eastell R, Brandi ML, Costa AG, D’Amour P, Shoback DM, Thakker RV. Diagnosis of asymptomatic primary hyperparathyroidism: proceedings of the Fourth International Workshop. J Clin Endocrinol Metab. 2014;99:3570-9.

37. Walker MD, Rubin M, Silverberg SJ. Nontraditional manifestations of primary hyperparathyroidism. J Clin Densitom Off J Int Soc Clin Densitom. 2013;16:40-7.

38. Silverberg SJ, Walker MD, Bilezikian JP. Asymptomatic primary hyperparathyroidism. J Clin Densitom Off J Int Soc Clin Densitom. 2013;16:14-21.

39. Talat N, Schulte KM. Clinical presentation, staging and long-term evolution of parathyroid cancer. Ann Surg Oncol. 2010;17:215674.

40. Hundahl SA, Fleming ID, Fremgen AM, Menck HR. Two hundred eighty-six cases of parathyroid carcinoma treated in the U.S. between 1985-1995: A National Cancer Data Base Report. The American College of Surgeons Commission on Cancer and the American Cancer Society. Cancer. 1999;86:538-44.

41. Arnold A, Lauter K. Genetics of hyperparathyroidism including parathyroid cancer. In: Refetoff REW, editor. Genetic diagnosis of endocrine disorders. San Diego: Academic Press; 2010:141148.

42. Giusti F, Cavalli L, Cavalli T, Brandi ML. Hereditary hyperparathyroidism syndromes. J Clin Densitom Off J Int Soc Clin Densitom. 2013;16(1):69-74.

43. Pallauf A, Schopohl J, Makeschin M, Kirchner T, Reincke M. Lethal generalized calcinosis and hypercalcemic crisis in primary hyperparathyroidism. J Clin Endocrinol Metab. 2015;100:17-8.
44. Apel RL, Asa SL. The Parathyroid glands. In: LiVolsi V, Asa SL, editors. Endocrine pathology. Philadelphia: Churchill Livingstone; 2002:103-47.

45. Bindlish V, Freeman JL, Witterick IJ, Asa SL. Correlation of biochemical parameters with single parathyroid adenoma weight and volume. Head Neck. 2002;24:1000-3.

46. Silverberg SJ, Lewiecki EM, Mosekilde L, Peacock M, Rubin MR. Presentation of asymptomatic primary hyperparathyroidism: Proceedings of the third international workshop. J Clin Endocrinol Metab. 2009;94:351-65.

47. Habib Z, Kabaker A, Camacho P. Sporadic primary hyperparathyroidism: Medical and surgical updates. Expert Rev Endocrinol Metab. 2013;9:31-44.

48. Mackenzie-Feder J, Sirrs S, Anderson D, Sharif J, Khan A. Primary hyperparathyroidism: An overview. Int J Endocrinol. 2011;2011:251410.

49. Pepe J, Cipriani C, Pilotto R, De Lucia F, Castro C, Lenge L, Russo S, Guarnieri V, Scillitani A, Carnevale V, D’Erasmo E, Romagnoli E, Minisola S. Sporadic and hereditary primary hyperparathyroidism. J Endocrinol Invest. 2011;34(7 Suppl):40-4

50. JamalSA, Miller PD. Secondaryand tertiaryhyperparathyroidism. J Clin Densitom Off J Int Soc Clin Densitom. 2013;16:64-8.

51. Caron P, Simonds WF, Maiza JC, Rubin M, Cantor T, Rousseau L, Bilezikian JP, Souberbielle JC, D’Amour P. Nontruncated amino-terminal parathyroid hormone overproduction in two patients with parathyroid carcinoma: A possible link to HRPT2 gene inactivation. Clin Endocrinol (Oxf). 2011;74:694-8.

52. Rubin MR, Silverberg SJ, D'Amour P, Brossard JH, Rousseau L, Sliney J Jr, Cantor T, Bilezikian JP. An N-terminal molecular form of parathyroid hormone (PTH) distinct from $\mathrm{hPTH}(1$ $84)$ is overproduced in parathyroid carcinoma. Clin Chem. 2007;53:1470-6.

53. Caron P, Maiza JC, Renaud C, Cormier C, Barres BH, Souberbielle JC. High third generation/second generation PTH ratio in a patient with parathyroid carcinoma: Clinical utility of third generation/second generation $\mathrm{PTH}$ ratio in patients with primary hyperparathyroidism. Clin Endocrinol (Oxf). 2009;70:533-8.

54. Cavalier E, Daly AF, Betea D, Pruteanu-Apetrii PN, Delanaye P, Stubbs P, Bradwell AR, Chapelle JP, Beckers A. The ratio of parathyroid hormone as measured by third- and secondgeneration assays as a marker for parathyroid carcinoma. J Clin Endocrinol Metab. 2010;95:3745-9.

55. Segiet OA, Deska M, Michalski M, Gawrychowski J, Wojnicz R. Molecular profiling in primary hyperparathyroidism. Head Neck. 2015;37:299-307.

56. Wilkins BJ, Jr JSL. Non-Functional Parathyroid Carcinoma: Nonfunctional parathyroid carcinoma: A review of the literature and report of a case requiring extensive surgery. Head Neck Pathol. 2009;3:140-9.

57. Sidhu PS, Talat N, Patel P, Mulholland NJ, Schulte KM Ultrasound features of malignancy in the preoperative diagnosis of parathyroid cancer: A retrospective analysis of parathyroid tumours larger than 15 mm. Eur Radiol. 2011;21:1865-73. 
58. Cheung K, Wang TS, Farrokhyar F, Roman SA, Sosa JA. A Metaanalysis of preoperative localization techniques for patients with primary hyperparathyroidism. Ann Surg Oncol. 2011;19:577-83.

59. Hara H, Igarashi A, Yano Y, Yashiro T, Ueno E, Aiyoshi Y, Ito K, Obara T. Ultrasonographic features of parathyroid carcinoma. Endocr J. 2001;48:213-7.

60. Kunstman JW, Kirsch JD, Mahajan A, Udelsman R. Clinical review: Parathyroid localization and implications for clinical management. J Clin Endocrinol Metab. 2013;98:902-12.

61. Bilezikian JP, Brandi ML, Eastell R, Silverberg SJ, Udelsman R, Marcocci C, Potts JT Jr. Guidelines for the management of asymptomatic primary hyperparathyroidism: summary statement from the Fourth International Workshop. J Clin Endocrinol Metab. 2014;99:3561-9.

62. Cipriani C, Biamonte F, Costa AG, Zhang C, Biondi P, Diacinti D, Pepe J, Piemonte S, Scillitani A, Minisola S, Bilezikian JP. Prevalence of kidney stones and vertebral fractures in primary hyperparathyroidism using imaging technology. J Clin Endocrinol Metab. 2015;100:1309-15.

63. Guerin C, Lowery A, Gabriel S, Castinetti F, Philippon M, Vaillant-Lombard J, Loundou A, Henry JF, Sebag F, Taïeb D. Preoperative imaging for focused parathyroidectomy: Making a good strategy even better. Eur J Endocrinol. 2015;172:519-26.

64. Treglia G, Sadeghi R, Schalin-Jäntii C, Caldarella C, Ceriani L, Giovanella L. Detection rate of $(99 \mathrm{~m})$ Tc-MIBI SPECT/ $\mathrm{CT}$ in the preoperative planning of patients with primary hyperparathyroidism: A meta-analysis. Head Neck. March 2015. (Epub ahead of print)

65. Elgazzar AH, Alenezi SA. Parathyroid gland. In: Elgazzar AH, editor. The Pathophysiologic basis of nuclear medicine. New York: Springer International Publishing; 2015. 281-303.

66. Phillips CD, Shatzkes DR. Imaging of the parathyroid glands. Semin Ultrasound CT MRI. 2012;33:123-9.

67. Hindié E, Ugur O, Fuster D, O’Doherty M, Grassetto G, Ureña P, Kettle A, Gulec SA, Pons F, Rubello D; Parathyroid Task Group of the EANM. 2009 EANM parathyroid guidelines. Eur J Nucl Med Mol Imaging. 2009;36:1201-16.

68. Michaud L, Burgess A, Huchet V, Lefèvre M, Tassart M, Ohnona J, Kerrou K, Balogova S, Talbot JN, Périé S. Is 18F-fluorocholinepositron emission tomography/computerized tomography a new imaging tool for detecting hyperfunctioning parathyroid glands in primary or secondary hyperparathyroidism? J Clin Endocrinol Metab. 2014;99:4531-6.

69. Busaidy NL, Jimenez C, Habra MA, Schultz PN, El-Naggar AK, Clayman GL, Asper JA, Diaz EM Jr, Evans DB, Gagel RF, Garden A, Hoff AO, Lee JE, Morrison WH, Rosenthal DI, Sherman SI, Sturgis EM, Waguespack SG, Weber RS, Wirfel K, VassilopoulouSellin R. Parathyroid carcinoma: A 22-year experience. Head Neck. 2004;26:716-26.

70. Baloch ZW, LiVolsi VA. Parathyroid Glands, Pathology, In: Reference Module in Biomedical Sciences, Elsevier, 2014, ISBN 9780128012383, http://dx.doi.org/10.1016/B978-0-12-8012383.03782-X. (http://www.sciencedirect.com/science/article/pii/ B978012801238303782X)

71. Duan K, Gomez Hernandez K, Mete O. Clinicopathological correlates of hyperparathyroidism. J Clin Pathol. 2015. In press.
72. Van der Walt J. Pathology of the parathyroid glands. Diagn Histopathol. 2012;18:221-33.

73. Endocrine Pathology. Mete O, Asa SL, editors. Cambridge University Press; 2016

74. Grimelius L, Akerström G, Bondeson L, Juhlin C, Johansson H, Ljunghall S, Rastad J. The role of the pathologist in diagnosis and surgical decision making in hyperparathyroidism. World J Surg. 1991;15:698-705.

75. Barczynski M, Konturek A, Hubalewska-Dydejczyk A, Cichon S, Nowak W. Evaluation of Halle, Miami, Rome, and Vienna intraoperative iPTH assay criteria in guiding minimally invasive parathyroidectomy. Langenbecks Arch Surg Dtsch Ges Für Chir. 2009;394:843-9.

76. Vignali E, Picone A, Materazzi G, Steffe S, Berti P, Cianferotti L, Cetani F, Ambrogini E, Miccoli P, Pinchera A, Marcocci C. A quick intraoperative parathyroid hormone assay in the surgical management of patients with primary hyperparathyroidism: A study of 206 consecutive cases. Eur J Endocrinol Eur Fed Endocr Soc. 2002;146:783-8

77. Carneiro DM, Solorzano CC, Nader MC, Ramirez M, Irvin GL. Comparison of intraoperative iPTH assay (QPTH) criteria in guiding parathyroidectomy: Which criterion is the most accurate? Surgery. 2003;134:973-9; discussion 979-81.

78. Kameyama DK, Takami H. Proposal for the histological classification of parathyroid carcinoma. Endocr Pathol. 2005; 16:49-52.

79. DeLellis RA. Pathology and Genetics of Tumours of Endocrine Organs. Lyon:IARC; 2004.

80. Alwaheeb S, Rambaldini G, Boerner S, Coiré C, Fiser J, Asa SL. Worrisome histologic alterations following fine-needle aspiration of the parathyroid. J Clin Pathol. 2006;59:1094-6.

81. Chow LT, Metreweli C, King WW, Tang NL, Allen PW. Histological changes of parathyroid adenoma after percutaneous injection of ethanol. Histopathology. 1997;30:87-9.

82. Elgoweini M, Chetty R. Hyalinizing parathyroid adenoma and hyperplasia: Report of 3 cases of an unusual histologic variant. Ann Diagn Pathol. 2011;15:329-32.

83. Bondeson L, Sandelin K, Grimelius L. Histopathological variables and DNA cytometry in parathyroid carcinoma. Am J Surg Pathol. 1993;17:820-9.

84. Johnson SJ. Changing clinicopathological practice in parathyroid disease. Histopathology. 2010;56:835-51.

85. Erovic BM, Harris L, Jamali M, Goldstein DP, Irish JC, Asa SL, Mete O. Biomarkers of parathyroid carcinoma. Endocr Pathol. 2012;23:221-31.

86. Mete O, Asa SL. Pathological definition and clinical significance of vascular invasion in thyroid carcinomas of follicular epithelial derivation. Mod Pathol. 2011;24:1545-52.

87. Fernandez-Ranvier GG, Khanafshar E, Jensen K, Zarnegar R, Lee J, Kebebew E, Duh QY, Clark OH. Parathyroid carcinoma, atypical parathyroid adenoma, or parathyromatosis? Cancer. 2007;110:255-64. 
88. Juhlin CC, Nilsson IL, Johansson K, Haglund F, Villablanca A, Höög A, Larsson C. Parafibromin and APC as Screening Markers for Malignant Potential in Atypical Parathyroid Adenomas. Endocr Pathol. 2010;21:166-77.

89. Kruijff S, Sidhu SB, Sywak MS, Gill AJ, Delbridge LW. Negative Parafibromin Staining Predicts Malignant Behavior in Atypical Parathyroid Adenomas. Ann Surg Oncol. 2013;21:426-33.

90. Kelly TG, Shattuck TM, Reyes-Mugica M, Stewart AF, Simonds WF, Udelsman R, Arnold A, Carpenter TO. Surveillance for early detection of aggressive parathyroid disease: Carcinoma and atypical adenoma in familial isolated hyperparathyroidism associated with a germline HRPT2 mutation. J Bone Miner Res. 2006;21:1666-71.

91. Truran PP, Johnson SJ, Bliss RD, Lennard TWJ, Aspinall SR. Parafibromin, Galectin-3, PGP9.5, Ki67, and Cyclin D1: Using an Immunohistochemical Panel to Aid in the Diagnosis of Parathyroid Cancer. World J Surg. 2014;38:2845-54.

92. Gill AJ, Clarkson A, Gimm O, Keil J, Dralle H, Howell VM, Marsh DJ. Loss of nuclear expression of parafibromin distinguishes parathyroid carcinomas and hyperparathyroidismjaw tumor (HPT-JT) syndrome-related adenomas from sporadic parathyroid adenomas and hyperplasias. Am J Surg Pathol. 2006;30:1140-9.

93. Erickson LA, Jin L, Wollan P, Thompson GB, van Heerden JA, Lloyd RV. Parathyroid Hyperplasia, Adenomas, and Carcinomas: Differential Expression of p27Kip1 Protein. Am J Surg Pathol. 1999;23:288-95.

94. Juhlin CC, Haglund F, Obara T, Arnold A, Larsson C, Höög A. Absence of nucleolar parafibromin immunoreactivity in subsets of parathyroid malignant tumours. Virchows Arch Int J Pathol. 2011;459:47-53.

95. Cetani F, Ambrogini E, Viacava P, Pardi E, Fanelli G, Naccarato AG, Borsari S, Lemmi M, Berti P, Miccoli P, Pinchera A, Marcocci C. Should parafibromin staining replace HRTP2 gene analysis as an additional tool for histologic diagnosis of parathyroid carcinoma? Eur J Endocrinol. 2007;156:547-54.

96. Juhlin CC, Villablanca A, Sandelin K, Haglund F, Nordenström J, Forsberg L, Bränström R, Obara T, Arnold A, Larsson C, Höög A. Parafibromin immunoreactivity: Its use as an additional diagnostic marker for parathyroid tumor classification. Endocr Relat Cancer. 2007;14:501-12.

97. Bergero N, De Pompa R, Sacerdote C, Gasparri G, Volante M, Bussolati G, Papotti M. Galectin-3 expression in parathyroid carcinoma: Immunohistochemical study of 26 cases. Hum Pathol. 2005;36:908-914.

98. Saggiorato E, Bergero N, Volante M, Bacillo E, Rosas R, Gasparri G, Orlandi F, Papotti M. Galectin-3 and Ki-67 expression in multiglandular parathyroid lesions. Am J Clin Pathol. 2006;126:59-66.

99. Starker LF, Svedlund J, Udelsman R, Dralle H, Akerström G, Westin G, Lifton RP, Björklund P, Carling T. The DNA methylome of benign and malignant parathyroid tumors. Genes Chromosomes Cancer. 2011;50:735-45.

100. Costa-Guda J, Arnold A. Genetic and epigenetic changes in sporadic endocrine tumors: Parathyroid tumors. Mol Cell Endocrinol. 2014;386:46-54.
101. Rodríguez-Rodero S, Delgado-Álvarez E, Fernández AF, Fernández-Morera JL, Menéndez-Torre E, Fraga MF. Epigenetic alterations in endocrine-related cancer. Endocr Relat Cancer. 2014;21:R319-30.

102. Fonseca AL, Kugelberg J, Starker LF, Scholl U, Choi M, Hellman P, Åkerström G, Westin G, Lifton RP, Björklund P, Carling T. Comprehensive DNA methylation analysis of benign and malignant adrenocortical tumors. Genes Chromosomes Cancer. 2012;51:949-60.

103. Sulaiman L, Juhlin CC, Nilsson IL, Fotouhi O, Larsson C, Hashemi J. Global and gene-specific promoter methylation analysis in primary hyperparathyroidism. Epigenetics. 2013;8:646-55.

104. Shattuck TM, Välimäki S, Obara T, Gaz RD, Clark OH, Shoback D, Wierman ME, Tojo K, Robbins CM, Carpten JD, Farnebo LO, Larsson C, Arnold A. Somatic and germ-line mutations of the HRPT2 gene in sporadic parathyroid carcinoma. N Engl J Med. 2003;349:1722-9.

105. Cetani F, Pardi E, Borsari S, Viacava P, Dipollina G, Cianferotti L, Ambrogini E, Gazzerro E, Colussi G, Berti P, Miccoli P, Pinchera A, Marcocci C. Genetic analyses of the HRPT2 gene in primary hyperparathyroidism: Germline and somatic mutations in familial and sporadic parathyroid tumors. J Clin Endocrinol Metab. 2004;89:5583-91.

106. Cetani F, Banti C, Pardi E, Borsari S, Viacava P, Miccoli P, Torregrossa L, Basolo F, Pelizzo MR, Rugge M, Pennelli G, Gasparri G, Papotti M, Volante M, Vignali E, Saponaro F, Marcocci C. CDC73 mutational status and loss of parafibromin in the outcome of parathyroid cancer. Endocr Connect. 2013;2:186-95.

107. Kim HK, Oh YL, Kim SH, Lee DY, Kang HC, Lee JI, Jang HW, Hur KY, Kim JH, Min YK, Chung JH, Kim SW. Parafibromin immunohistochemical staining to differentiate parathyroid carcinoma from parathyroid adenoma. Head Neck. 2012;34:2016.

108. Chrisoulidou A, Mandanas S, Mitsakis P, Iliadou PK, Manafis K, Flaris N, Boudina M, Mathiopoulou L, Pazaitou-Panayiotou K. Parathyroid involvement in thyroid cancer: An unforeseen event. World J Surg Oncol. 2012;10:121.

109. Lee SH, Kim BH, Bae MJ, Yi YS, Kim WJ, Jeon YK, Kim SS, Kim YK, Kim IJ. Concurrence of primary hyperparathyroidism and metastatic breast carcinoma affected a parathyroid gland. J Clin Endocrinol Metab. 2013;98:3127-30.

110. Papi G, Corrado S, Fadda G, Maiorana A, Maccio L, Corsello SM, Pontecorvi A. Parathyroid gland involvement by thyroid cancer: Results from a large series of thyroidectomies performed in two italian university hospitals and review of the literature. J Thyroid Res. 2014;2014:e685425.

111. Erickson LA. Metastases to Parathyroid. In: Atlas of Endocrine Pathology. Atlas of Anatomic Pathology. Springer New York; 2014:143-145.

112. Horwitz CA, Myers WPL, Foote FW. Secondary malignant tumors of the parathyroid glands. Am J Med. 1972;52:797-808.

113. Venkatraman L, Kalangutkar A, Russell CF. Primary hyperparathyroidism and metastatic carcinoma within parathyroid gland. J Clin Pathol. 2007;60:1058-60. 
114. Shifrin A, LiVolsi VA, Zheng M, Lann DE, Fomin S, Naylor EC, Mencel PJ, Fay AM, Erler BS, Matulewicz TJ. Neuroendocrine Thymic Carcinoma Metastatic to the Parathyroid Gland that was Reimplanted into the Forearm in Patient with Multiple Endocrine Neoplasia Type 1 Syndrome: A Challenging Management Dilemma. Endocr Pract. 2013;19:e163-7.

115. Duan K, Ezzat S, Asa SL, Mete O. Pancreatic Neuroendocrine Tumors Producing GHRH, GH, Ghrelin, PTH, or PTHrP. In: Rosa SL, Sessa F, eds. Pancreatic Neuroendocrine Neoplasms. Vol Springer International Publishing; 2015:125-39.

116. Tsolakis DA, Kanakis DG. Pancreatic Neuroendocrine Tumors. In: Islam MS, ed. Islets of Langerhans, 2. Ed. Springer Netherlands; 2014:1-29.

117. Kamp K, Feelders RA, van Adrichem RC, de Rijke YB, van Nederveen FH, Kwekkeboom DJ, de Herder WW. Parathyroid hormone-related peptide (PTHrP) secretion by gastroenteropancreatic neuroendocrine tumors (GEP-NETs): Clinical features, diagnosis, management, and follow-up. J Clin Endocrinol Metab. 2014;99:3060-9.

118. Nonaka D. Study of parathyroid transcription factor Gcm 2 expression in parathyroid lesions. Am J Surg Pathol. 2011;35:14551.

119. D’Agruma L, Coco M, Guarnieri V, Battista C, Canaff L, Salcuni AS, Corbetta S, Cetani F, Minisola S, Chiodini I, Eller-Vainicher C, Spada A, Marcocci C, Guglielmi G, Zini M, Clemente R, Wong BY, de Martino D, Scillitani A, Hendy GN, Cole DE. Increased prevalence of the GCM2 polymorphism, Y282D, in primary hyperparathyroidism: Analysis of three Italian cohorts. J Clin Endocrinol Metab. 2014;99:2794-8.

120. Ordóñez NG. Value of GATA3 immunostaining in the diagnosis of parathyroid tumors. Appl Immunohistochem Mol Morphol AIMM Off Publ Soc Appl Immunohistochem. 2014;22:756-61.

121. Han S-I, Tsunekage Y, Kataoka K. Gata3 cooperates with Gcm2 and MafB to activate parathyroid hormone gene expression by interacting with SP1. Mol Cell Endocrinol. 2015;411:113-20.

122. Manley NR. Embryology of the Parathyroid Glands. In: Brandi ML, Brown EM, eds. Hypoparathyroidism. Vol Springer Milan; 2015:11-8.

123. Mete O, Asa SL. Precursor lesions of endocrine system neoplasms. Pathology. 2013;45:316-30.

124. Hendy GN, Cole DEC. Genetic defects associated with familial and sporadic hyperparathyroidism. Front Horm Res. 2013;41:149-65.

125. Zhao J, Hu Y, Liao Q, Niu Z, Xing X, Xia W, Zhao Y. Gene identification of potential malignant parathyroid tumors phenotype in Chinese population. Endocr J. 2014;61:597-605.

126. Khan MW, Worcester EM, Straus FH, Khan S, Staszak V, Kaplan EL. Parathyroid carcinoma in secondary and tertiary hyperparathyroidism1. J Am Coll Surg. 2004;199:312-9.

127. Nasrallah MP, Fraker DL, LiVolsi VA. Parathyroid carcinoma in the setting of tertiaryhyperparathyroidism after renal transplant. Endocr Pathol. 2014;25:433-5.

128. Verdelli C, Forno I, Vaira V, Corbetta S. Epigenetic alterations in human parathyroid tumors. Endocrine. 2015;49:324-32.
129. Alfadda TI, Saleh AMA, Houillier P, Geibel JP. Calciumsensing receptor 20 years later. Am J Physiol - Cell Physiol. 2014;307:C221-31.

130. Brown EM. Clinical lessons from the calcium-sensing receptor. Nat Rev Endocrinol. 2007;3:122-33.

131. Sharretts JM, Simonds WF. Clinical and molecular genetics of parathyroid neoplasms. Best Pract Res Clin Endocrinol Metab. 2010;24:491-502.

132. Arnold A, Shattuck TM, Mallya SM, Krebs LJ, Costa J, Gallagher J, Wild Y, Saucier K. Molecular pathogenesis of primary hyperparathyroidism. J Bone Miner Res. 2002;17 Suppl 2:N30-6.

133. Varshney S, Bhadada SK, Sachdeva N, Arya AK, Saikia UN, Behera A, Rao SD. Methylation Status of the CpG Islands in Vitamin D and Calcium-Sensing Receptor Gene Promoters Does Not Explain the Reduced Gene Expressions in Parathyroid Adenomas. J Clin Endocrinol Metab. 2013;98:E1631-5.

134. Varshney S, Bhadada SK, Saikia UN, Sachdeva N, Behera A, Arya AK, Sharma S, Bhansali A, Mithal A, Rao SD. Simultaneous expression analysis of vitamin D receptor, calcium-sensing receptor, cyclin D1, and PTH in symptomatic primary hyperparathyroidism in Asian Indians. Eur J Endocrinol. 2013;169:109-16

135. Sudhaker Rao D, Han ZH, Phillips ER, Palnitkar S, Parfitt AM. Reduced vitamin D receptor expression in parathyroid adenomas: Implications for pathogenesis. Clin Endocrinol (Oxf). 2000;53:373-81.

136. Corbetta S, Mantovani G, Lania A, Borgato S, Vicentini L, Beretta E, Faglia G, Di Blasio AM, Spada A. Calcium-sensing receptor expression and signalling in human parathyroid adenomas and primary hyperplasia. Clin Endocrinol (Oxf). 2000;52:339-48.

137. Brennan SC, Thiem U, Roth S, Aggarwal A, Fetahu ISh, Tennakoon S, Gomes AR, Brandi ML, Bruggeman F, Mentaverri $\mathrm{R}$, Riccardi D, Kallay E. Calcium sensing receptor signalling in physiology and cancer. Biochim Biophys Acta. 2013;1833:173244.

138. Cetani F, Pardi E, Borsari S, Marcocci C. Molecular pathogenesis of primary hyperparathyroidism. J Endocrinol Invest. 2011;34(7 Suppl):35-9.

139. Farnebo F, Enberg U, Grimelius L, Bäckdahl M, Schalling M, Larsson C, Farnebo LO. Tumor-specific decreased expression of calcium sensing receptor messenger ribonucleic acid in sporadic primary hyperparathyroidism. J Clin Endocrinol Metab. 1997;82:3481-6.

140. Yano S, Sugimoto T, Tsukamoto T, Chihara K, Kobayashi A, Kitazawa S, Maeda S, Kitazawa R. Association of decreased calcium-sensing receptor expression with proliferation of parathyroid cells in secondary hyperparathyroidism. Kidney Int. 2000;58:1980-6.

141. Yano S, Sugimoto T, Tsukamoto T, Chihara K, Kobayashi A, Kitazawa S, Maeda S, Kitazawa R. Decrease in vitamin D receptor and calcium-sensing receptor in highly proliferative parathyroid adenomas. Eur J Endocrinol. 2003;148:403-11.

142. Carling T, Rastad J, Szabó E, Westin G, Akerström G. Reduced parathyroid vitamin $\mathrm{D}$ receptor messenger ribonucleic acid levels in primary and secondary hyperparathyroidism. J Clin Endocrinol Metab. 2000;85:2000-3. 
143. Rodriguez M, Canalejo A, Garfia B, Aguilera E, Almaden Y. Pathogenesis of refractory secondary hyperparathyroidism. Kidney Int Suppl. 2002;80:155-60.

144. Grzela T, Chudzinski W, Lasiecka Z, Niderla J, Wilczynski G, Gornicka B, Wasiutynski A, Durlik M, Boszczyk A, BrawuraBiskupski-Samaha R, Dziunycz P, Milewski L, Lazarczyk M, Lazarczyk M, Nawrot I. The calcium-sensing receptor and vitamin $\mathrm{D}$ receptor expression in tertiary hyperparathyroidism. Int J Mol Med. 2006;17:779-83.

145. Alvelos MI, Mendes M, Soares P. Molecular Alterations in Sporadic Primary Hyperparathyroidism. Genet Res Int. 2011;2011:e275802.

146. Macleod RJ. CaSR function in the intestine: Hormone secretion, electrolyte absorption and secretion, paracrine non-canonical Wnt signaling and colonic crypt cell proliferation. Best Pract Res Clin Endocrinol Metab. 2013;27:385-402.

147. Corbetta S, Eller-Vainicher C, Vicentini L, Lania A, Mantovani G, Beck-Peccoz P, Spada A. Modulation of cyclin D1 expression in human tumoral parathyroid cells: Effects of growth factors and calcium sensing receptor activation. Cancer Lett. 2007;255:3441.

148. Saidak Z, Mentaverri R, Brown EM. The Role of the calciumsensing receptor in the development and progression of cancer. Endocr Rev. 2009;30:178-95.

149. Kauffmann RM, Juhlin CC, Fohn LE, Broome JT, Phay JE. Parathyroid carcinoma arising from four-gland hyperplasia. Endocr Pract Off J Am Coll Endocrinol Am Assoc Clin Endocrinol. 2011;17:e37-e42.

150. Hsi ED, Zukerberg LR, Yang WI, Arnold A. Cyclin D1/PRAD1 expression in parathyroid adenomas: An immunohistochemical study. J Clin Endocrinol Metab. 1996;81:1736-9.

151. Imanishi Y, Hosokawa Y, Yoshimoto K, Schipani E, Mallya S, Papanikolaou A, Kifor O, Tokura T, Sablosky M, Ledgard F, Gronowicz G, Wang TC, Schmidt EV, Hall C, Brown EM, Bronson R, Arnold A. Primary hyperparathyroidism caused by parathyroid-targeted overexpression of cyclin D1 in transgenic mice. J Clin Invest. 2001;107:1093-102.

152. Hemmer S, Wasenius VM, Haglund C, Zhu Y, Knuutila S, Franssila K, Joensuu H. Deletion of 11q23 and Cyclin D1 Overexpression Are Frequent Aberrations in Parathyroid Adenomas. Am J Pathol. 2001;158:1355-62.

153. Zhao L, Sun LH, Liu DM, He XY, Tao B, Ning G, Liu JM, Zhao HY. Copy number variation in CCND1 gene is implicated in the pathogenesis of sporadic parathyroid carcinoma. World J Surg. 2014;38:1730-7.

154. Arnold A, Soong CP. New role for ZFX in oncogenesis. Cell Cycle. 2014;13:3465-6.

155. Soong C-P, Arnold A. Recurrent ZFX mutations in human sporadic parathyroid adenomas. Oncoscience. 2014;1:360-6.

156. Connell-Crowley L, Harper JW, Goodrich DW. Cyclin D1/Cdk4 regulates retinoblastoma protein-mediated cell cycle arrest by site-specific phosphorylation. Mol Biol Cell. 1997;8(2):287-301.

157. Mallya SM, Arnold A. Cyclin D1 in parathyroid disease. Front Biosci J Virtual Libr. 2000;5:D367-71.
158. Vasef MA, Brynes RK, Sturm M, Bromley C, Robinson RA. Expression of cyclin D1 in parathyroid carcinomas, adenomas, and hyperplasias: A paraffin immunohistochemical study. Mod Pathol Off J U S Can Acad Pathol Inc. 1999;12:412-6.

159. Costa-Guda J, Marinoni I, Molatore S, Pellegata NS, Arnold A. Somatic mutation and germline sequence abnormalities in $\mathrm{CDKN1B}$, encoding p27Kip1, in sporadic parathyroid adenomas. J Clin Endocrinol Metab. 2011;96:E701-6.

160. Costa-Guda J, Soong C-P, Parekh VI, Agarwal SK, Arnold A. Germline and somatic mutations in cyclin-dependent kinase inhibitor genes CDKN1A, CDKN2B, and CDKN2C in sporadic parathyroid adenomas. Horm Cancer. 2013;4:301-7.

161. Gluick T, Yuan Z, Libutti SK, Marx SJ. Mutations in CDKN2C (p18) and CDKN2D (p19) may cause sporadic parathyroid adenoma. Endocr Relat Cancer. 2013;20:L27-9.

162. Buchwald PC, Åkerström G, Westin G. Reduced p18INK4c, p21CIP1/WAF1 and p27KIP1 mRNA levels in tumours of primary and secondary hyperparathyroidism. Clin Endocrinol (Oxf). 2004;60:389-93.

163. Svedlund J, Barazeghi E, Stålberg P, Hellman P, Åkerström G, Björklund P, Westin G. The histone methyltransferase EZH2, an oncogene common to benign and malignant parathyroid tumors. Endocr Relat Cancer. 2014;21:231-9.

164. Kasaian K, Wiseman SM, Thiessen N, Mungall KL, Corbett RD, Qian JQ, Nip KM, He A, Tse K, Chuah E, Varhol RJ, Pandoh P, McDonald H, Zeng T, Tam A, Schein J, Birol I, Mungall AJ, Moore RA, Zhao Y, Hirst M, Marra MA, Walker BA, Jones SJ. Complete genomic landscape of a recurring sporadic parathyroid carcinoma. J Pathol. 2013;230:249-60.

165. Pausova Z, Soliman E, Amizuka N, Janicic N, Konrad EM, Arnold A, Goltzman D, Hendy GN. Role of the RET proto-oncogene in sporadic hyperparathyroidism and in hyperparathyroidism of multiple endocrine neoplasia type 2. J Clin Endocrinol Metab. 1996;81:2711-8.

166. Jenkins PJ, Satta MA, Simmgen M, Drake WM, Williamson C, Lowe DG, Britton K, Chew SL, Thakker RV, Besser GM. Metastatic parathyroid carcinoma in the MEN2A syndrome. Clin Endocrinol (Oxf). 1997;47:747-51.

167. Shtutman M, Zhurinsky J, Simcha I, Albanese C, D’Amico M, Pestell R, Ben-Ze'ev A. The cyclin D1 gene is a target of the betacatenin/LEF-1 pathway. Proc Natl Acad Sci U S A. 1999;96:55227.

168. Svedlund J, Aurén M, Sundström M, Dralle H, Akerström G, Björklund P, Westin G. Aberrant WNT/ $\beta$-catenin signaling in parathyroid carcinoma. Mol Cancer. 2010;9:294.

169. Juhlin CC, Haglund F, Villablanca A, Forsberg L, Sandelin K, Bränström R, Larsson C, Höög A. Loss of expression for the Wnt pathway components adenomatous polyposis coli and glycogen synthase kinase 3-beta in parathyroid carcinomas. Int J Oncol. 2009;34:481-92.

170. Björklund P, Akerström G, Westin G. Accumulation of nonphosphorylated beta-catenin and c-myc in primary and uremic secondary hyperparathyroid tumors. J Clin Endocrinol Metab. 2007;92:338-44. 
171. Berthon A, Martinez A, Bertherat J, Val P. Wnt/ $\beta$-catenin signalling in adrenal physiology and tumour development. Mol Cell Endocrinol. 2012;351:87-95.

172. Starker LF, Fonseca A, Åkerström G, Björklund P, Westin G, Carling T. Evidence of a stabilizing mutation of $\beta$-catenin encoded by CTNNB1 exon 3 in a large series of sporadic parathyroid adenomas. Endocrine. 2012;42:612-5.

173. Björklund P, Åkerström G, Westin G. An LRP5 Receptor with Internal Deletion in Hyperparathyroid Tumors with Implications for Deregulated WNT/ $\beta$-Catenin Signaling. PLoS Med. 2007;4:e328.

174. Simonds WF. Ruling Out a Suspect: The Role of $\beta$-Catenin Mutation in Benign Parathyroid Neoplasia. J Clin Endocrinol Metab. 2007;92:1235-6.

175. Guarnieri V, Baorda F, Battista C, Bisceglia M, Balsamo T, Gruppioni E, Fiorentino M, Muscarella LA, Coco M, Barbano R, Corbetta S, Spada A, Cole DE, Canaff L, Hendy GN, Carella $\mathrm{M}$, Scillitani A. A rare S33C mutation of CTNNB1 encoding $\beta$-catenin in a parathyroid adenoma found in an Italian primary hyperparathyroid cohort. Endocrine. 2011;41:152-5.

176. Björklund P, Lindberg D, Åkerström G, Westin G. Stabilizing mutation of CTNNB1/beta-catenin and protein accumulation analyzed in a large series of parathyroid tumors of Swedish patients. Mol Cancer. 2008;7:1-8.

177. Westin G, Björklund P, Åkerström G. Molecular Genetics of Parathyroid Disease. World J Surg. 2009;33:2224-33.

178. Alvelos MI, Vinagre J, Fonseca E, Barbosa E, Teixeira-Gomes J, Sobrinho-Simões M, Soares P. MEN1 intragenic deletions may represent the most prevalent somatic event in sporadic primary hyperparathyroidism. Eur J Endocrinol. 2013;168:119-28.

179. Heppner C, Kester MB, Agarwal SK, Debelenko LV, EmmertBuck MR, Guru SC, Manickam P, Olufemi SE, Skarulis MC, Doppman JL, Alexander RH, Kim YS, Saggar SK, Lubensky IA, Zhuang Z, Liotta LA, Chandrasekharappa SC, Collins FS, Spiegel AM, Burns AL, Marx SJ. Somatic mutation of the MEN1 gene in parathyroid tumours. Nat Genet. 1997;16:375-8.

180. Cromer MK, Starker LF, Choi M, Udelsman R, Nelson-Williams C, Lifton RP, Carling T. Identification of somatic mutations in parathyroid tumors using whole-exome sequencing. J Clin Endocrinol Metab. 2012;97:E1774-81.

181. Haven CJ, van Puijenbroek M, Tan MH, Teh BT, Fleuren GJ, van Wezel T, Morreau H. Identification of MEN1 and HRPT2 somatic mutations in paraffin-embedded (sporadic) parathyroid carcinomas. Clin Endocrinol (Oxf). 2007;67:370-6.

182. Cao Y, Liu R, Jiang X, Lu J, Jiang J, Zhang C, Li X, Ning G. Nuclear-cytoplasmic shuttling of menin regulates nuclear translocation of \{beta\}-catenin. Mol Cell Biol. 2009;29:5477-87.

183. Balogh K, Patócs A, Hunyady L, Rácz K. Menin dynamics and functional insight: Take your partners. Mol Cell Endocrinol. 2010;326:80-4.

184. Juhlin CC, Kiss NB, Villablanca A, Haglund F, Nordenström J, Höög A, Larsson C. Frequent promoter hypermethylation of the APC and RASSF1A tumour suppressors in parathyroid tumours. PLoS ONE. 2010;5:e9472.
185. Bilezikian JP, Marcus R, Levine MA, Marcocci C, Silverberg SJ, Jr JTP. The Parathyroids: Basic and Clinical Concepts. Academic Press; 2014.

186. Howell VM, Gill A, Clarkson A, Nelson AE, Dunne R, Delbridge LW, Robinson BG, Teh BT, Gimm O, Marsh DJ. Accuracy of combined protein gene product 9.5 and parafibromin markers for immunohistochemical diagnosis of parathyroid carcinoma. J Clin Endocrinol Metab. 2009;94:434-41.

187. Krebs LJ, Shattuck TM, Arnold A. HRPT2 mutational analysis of typical sporadic parathyroid adenomas. J Clin Endocrinol Metab. 2005;90:5015-7.

188. Svedlund J, Koskinen Edblom S, Marquez VE, Åkerström G, Björklund P, Westin G. Hypermethylated in Cancer 1 (HIC1), a Tumor Suppressor Gene Epigenetically Deregulated in Hyperparathyroid Tumors by Histone H3 Lysine Modification. J Clin Endocrinol Metab. 2012;97:E1307-15.

189. Donninger H, Vos MD, Clark GJ. The RASSF1A tumor suppressor. J Cell Sci. 2007;120:3163-72.

190. Shivakumar L, Minna J, Sakamaki T, Pestell R, White MA. The RASSF1A tumor suppressor blocks cell cycle progression and inhibits cyclin D1 accumulation. Mol Cell Biol. 2002;22:4309-18.

191. Carling T, Du Y, Fang W, Correa P, Huang S. Intragenic allelic loss and promoter hypermethylation of the RIZ1 tumor suppressor gene in parathyroid tumors and pheochromocytomas. Surgery. 2003;134:932-9; discussion 939-40.

192. Verdelli C, Forno I, Vaira V, Corbetta S. MicroRNA deregulation in parathyroid tumours suggests an embryonic signature. J Endocrinol Invest. January 2015. (Epub ahead of print)

193. Yu W, McPherson JR, Stevenson M, van Eijk R, Heng HL, Newey P, Gan A, Ruano D, Huang D, Poon SL, Ong CK, van Wezel T, Cavaco B, Rozen SG, Tan P, Teh BT, Thakker RV, Morreau H. Whole-exome sequencing studies of parathyroid carcinomas reveal novel PRUNE2 mutations, distinctive mutational spectra related to APOBEC-catalyzed DNA mutagenesis and mutational enrichment in kinases associated with cell migration and invasion. J Clin Endocrinol Metab. 2015;100:E360-4.

194. Newey PJ, Nesbit MA, Rimmer AJ, Attar M, Head RT, Christie PT, Gorvin CM, Stechman M, Gregory L, Mihai R, Sadler G, McVean G, Buck D, Thakker RV. Whole-Exome Sequencing Studies of Nonhereditary (Sporadic) Parathyroid Adenomas. J Clin Endocrinol Metab. 2012;97:E1995-E2005.

195. Basceken SI, Genc V, Ersoz S, Sevim Y, Celik SU, Bayram IK. Is local resection sufficient for parathyroid carcinoma? Clinics. 2015;70:247-9.

196. Hsu K-T, Sippel RS, Chen H, Schneider DF. Is central lymph node dissection necessary for parathyroid carcinoma? Surgery. 2014;156:1336-41.

197. Sadler C, Gow KW, Beierle EA, Doski JJ, Langer M, Nuchtern JG, Vasudevan SA, Goldfarb M. Parathyroid carcinoma in more than 1,000 patients: A population-level analysis. Surgery. 2014;156:1622-9; discussion 1629-30.

198. Munson ND, Foote RL, Northcutt RC, Tiegs RD, Fitzpatrick LA, Grant CS, van Heerden JA, Thompson GB, Lloyd RV. Parathyroid carcinoma: Is there a role for adjuvant radiation therapy? Cancer. 2003;98:2378-84 
199. Fountas A, Andrikoula M, Giotaki Z, Limniati C, Tsakiridou E, Tigas S, Tsatsoulis A. The emerging role of denosumab in the long-term management of parathyroid carcinoma-related refractory hypercalcemia. Endocr Pract. 2015;21:468-73.

200. Karuppiah D, Thanabalasingham G, Shine B, Wang LM, Sadler GP, Karavitaki N, Grossman AB. Refractory hypercalcaemia secondary to parathyroid carcinoma: Response to high-dose denosumab. Eur J Endocrinol. 2014;171:K1-K5.

201. Vellanki P, Lange K, Elaraj D, Kopp PA, El Muayed M. Denosumab for management of parathyroid carcinomamediated hypercalcemia. J Clin Endocrinol Metab. 2014;99:38790.

202. Nadarasa K, Theodoraki A, Kurzawinski TR, Carpenter R, Bull J, Chung TT, Drake WM. Denosumab for management of refractory hypercalcaemia in recurrent parathyroid carcinoma. Eur J Endocrinol. 2014;171:L7-8.

203. Peacock M, Bilezikian JP, Bolognese MA, Borofsky M, Scumpia S, Sterling LR, Cheng S, Shoback D. Cinacalcet HCl reduces hypercalcemia in primary hyperparathyroidism across a wide spectrum of disease severity. J Clin Endocrinol Metab. 2011;96:E9-E18.

204. Marcocci C, Chanson P, Shoback D, Bilezikian J, FernandezCruz L, Orgiazzi J, Henzen C, Cheng S, Sterling LR, Lu J, Peacock M. Cinacalcet Reduces Serum Calcium Concentrations in Patients with Intractable Primary Hyperparathyroidism. J Clin Endocrinol Metab. 2009;94:2766-72.
205. Silverberg SJ, Rubin MR, Faiman C, Peacock M, Shoback DM, Smallridge RC, Schwanauer LE, Olson KA, Klassen P, Bilezikian JP. Cinacalcet hydrochloride reduces the serum calcium concentration in inoperable parathyroid carcinoma. J Clin Endocrinol Metab. 2007;92:3803-8.

206. Rodgers SE, Perrier ND. Parathyroid carcinoma: Curr Opin Oncol. 2006;18:16-22.

207. Szmuilowicz ED, Utiger RD. A case of parathyroid carcinoma with hypercalcemia responsive to cinacalcet therapy. Nat Rev Endocrinol. 2006;2:291-6.

208. Bradwell AR, Harvey TC. Control of hypercalcaemia of parathyroid carcinoma by immunisation. The Lancet. 1999;353:370-3.

209. Betea D, Bradwell AR, Harvey TC, Mead GP, Schmidt-Gayk H, Ghaye B, Daly AF, Beckers A. Hormonal and biochemical normalization and tumor shrinkage induced by anti-parathyroid hormone immunotherapy in a patient with metastatic parathyroid carcinoma. J Clin Endocrinol Metab. 2004;89:341320.

210. Horie I, Ando T, Inokuchi N, Mihara Y, Miura S, Imaizumi M, Usa T, Kinoshita N, Sekine I, Kamihara S, Eguchi K. First Japanese patient treated with parathyroid hormone peptide immunization for refractory hypercalcemia caused by metastatic parathyroid carcinoma. Endocr J. 2010;57:287-92. 